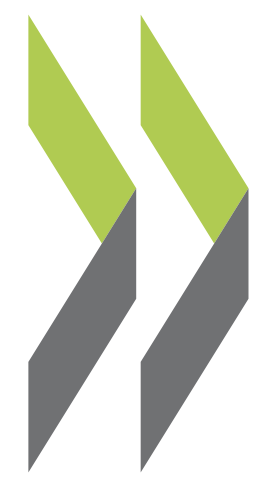

OECD Economics Department Working Papers No. 1555

Housing markets

and macroeconomic risks

\section{Maria Chiara Cavalleri,}

Boris Cournède,

Volker Ziemann 


\section{ECONOMICS DEPARTMENT}

\section{HOUSING MARKETS AND MACROECONOMIC RISKS}

\section{ECONOMICS DEPARTMENT WORKING PAPERS No. 1555}

\section{By Maria Chiara Cavalleri, Boris Cournède and Volker Ziemann}

OECD Working Papers should not be reported as representing the official views of the OECD or of its member countries. The opinions expressed and arguments employed are those of the author(s).

Authorised for publication by Alain de Serres, Deputy Director, Policy Studies Branch, Economics Department.

Document available in pdfformat only.

All Economics Department Working Papers are available at www.oecd.org/eco/workingpapers.

JT03449161 
OECD Working Papers should not be reported as representing the official views of the OECD or of its member countries. The opinions expressed and arguments employed are those of the author(s).

Working Papers describe preliminary results or research in progress by the author(s) and are published to stimulate discussion on a broad range of issues on which the OECD works.

Comments on Working Papers are welcomed, and may be sent to OECD Economics Department, 2 rue André Pascal, 75775 Paris Cedex 16, France, or by e-mail to eco.contact@oecd.org.

All Economics Department Working Papers are available at www.oecd.org/eco/workingpapers

The statistical data for Israel are supplied by and under the responsibility of the relevant Israeli authorities. The use of such data by the OECD is without prejudice to the status of the Golan Heights, East Jerusalem and Israeli settlements in the West Bank under the terms of international law.

On 25 May 2018, the OECD Council invited Colombia to become a Member. At the time of preparation the deposit of Colombia's instrument of accession to the OECD Convention was pending and therefore Colombia does not appear in the list of OECD Members and is not included in the OECD zone aggregates.

\section{(C) $\operatorname{OECD}(2019)$}

You can copy, download or print OECD content for your own use, and you can include excerpts from OECD publications, databases and multimedia products in your own documents, presentations, blogs, websites and teaching materials, provided that suitable acknowledgment of OECD as source and copyright owner is given. All requests for commercial use and translation rights should be submitted to rights@oecd.org. 


\section{ABSTRACT/RÉSUME \\ Housing Markets and Macroeconomic Risks}

Housing markets are large and highly volatile: they can thus create large macroeconomic risks. The current paper provides a bird's eye view of where the housing markets of major OECD economies currently stand. It then uses the results of recently developed models to provide indications of where macroeconomic risks exist. Finally, the paper draws on recent empirical analyses to suggest how economic policies can enhance economic resilience by reducing housing-related risks through macroprudential measures and housing market reforms (such as changes in rent regulation, taxation and land use policies).

JEL Classification codes: E37 ; E5 ; R31

Keywords: Housing, resilience, macroprudential policy, rent regulation, taxation, land use policy

$$
* * * * * * * * *
$$

\section{Marchés du logement et risques macroéconomiques}

Compte tenu de leur taille conséquente et de leur forte volatilité, les marchés du logement sont sources de risques macroéconomiques importants. Ce document propose une vue d'ensemble de la situation actuelle des marchés du logement des principales économies de l'OCDE. Il s'appuie ensuite sur les résultats de modèles mis au point récemment afin de recenser les risques macroéconomiques existants. Enfin, à partir d'analyses empiriques récentes, il propose des pistes quant à la manière dont les politiques macroéconomiques peuvent renforcer la résilience des économies en atténuant les risques liés au marché du logement, au moyen de mesures macroprudentielles et de réformes portant notamment sur la réglementation des loyers, sur la fiscalité immobilière et sur les politiques d'aménagement du territoire.

Classification JEL : E37 ; E5 ; R31

Mots-clés : Logement, resilience, politiques macroprudentielles, regulation du marché locatif, taxation, réglementation foncière 


\section{Table of contents}

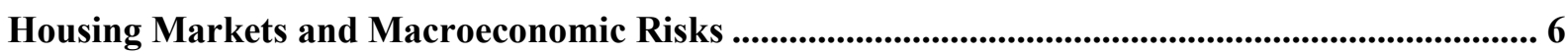

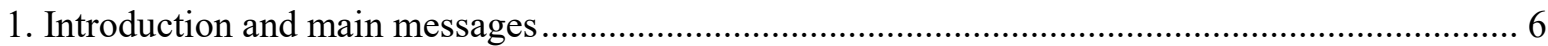

2. Why does the housing market matter so much for resilience?................................................... 8

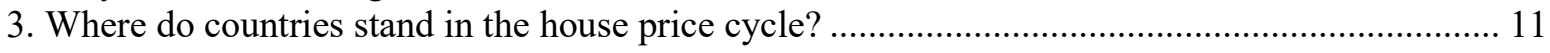

4. How large are current risks due to housing markets? ................................................................. 17

5. How can housing-related policies reduce the build-up of macroeconomic risks and improve

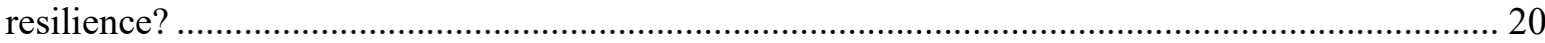

5.1. What is known about the effect of macroprudential and housing policies on resilience?...... 20

5.2. Framework for the analysis of macroprudential and housing policy effects on resilience ..... 26

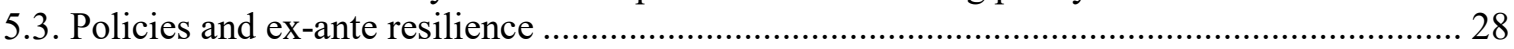

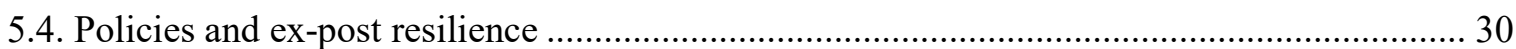

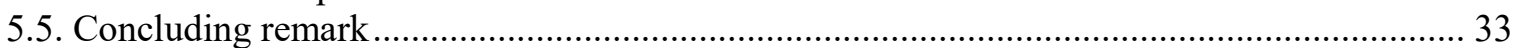

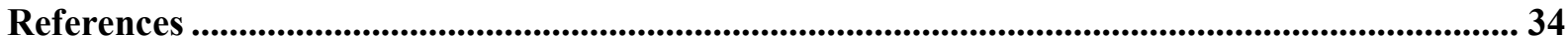

Annex A. Synchronisation of housing and business cycles by country............................................. 40

Annex B. Sources of the policy variables......................................................................................................... 43

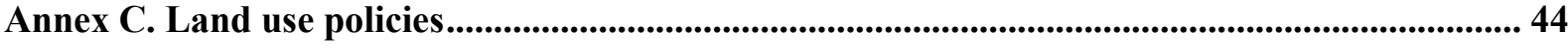

Annex D. Averages of policy variables over 2007-12 ............................................................................. 46

Annex E. Housing policies and resilience indicators ...................................................................47

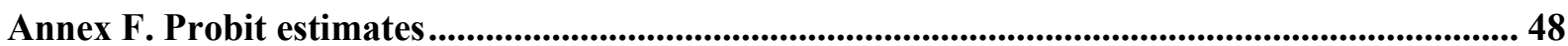

\section{Tables}

Table 1. Severe downturn probabilities: The global financial crisis versus now ….............................. 18

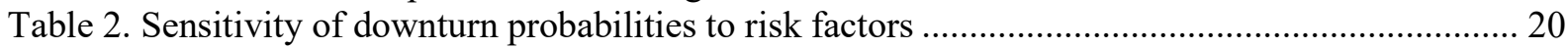

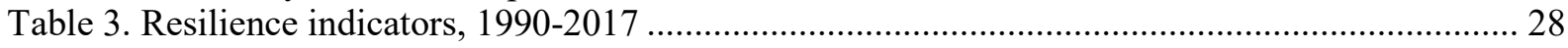

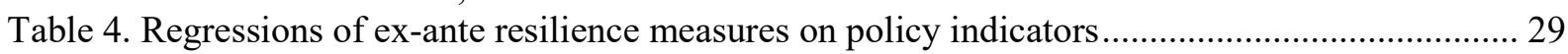

Figures

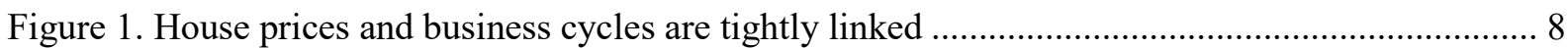

Figure 2. House price cycles have often been associated with severe recessions ................................ 9

Figure 3. Cyclical behaviour of output, house prices and residential investment ................................. 10

Figure 4. House price developments since the global financial crisis .................................................. 11

Figure 5. Regional house price growth differences are stark in some countries .................................. 12

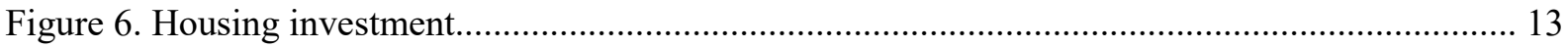

Figure 7. Debt weighs less on households despite limited deleveraging in most countries .................. 13

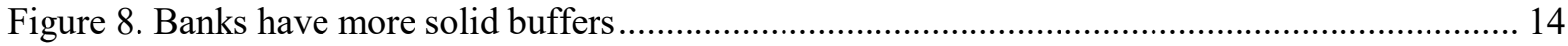

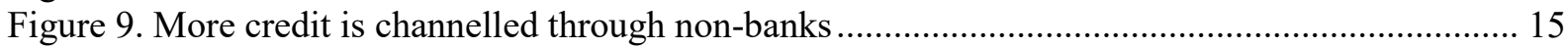

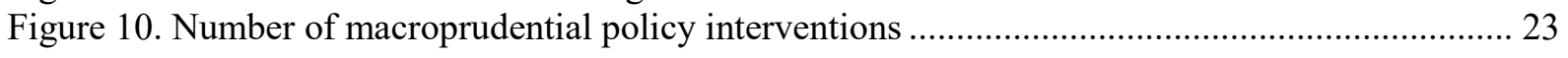




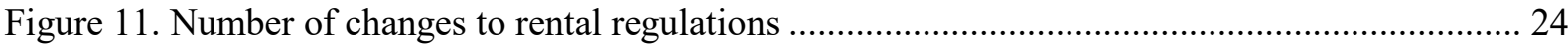

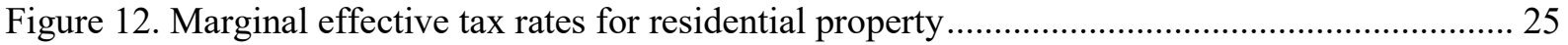

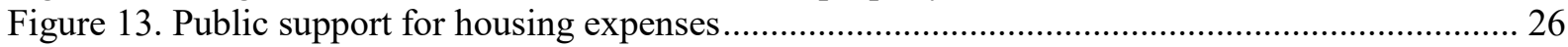

Figure 14. A resilience framework for housing-related shocks............................................................ 27

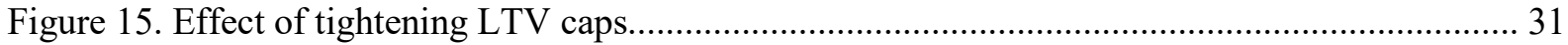

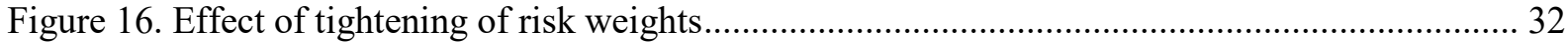

\section{Boxes}

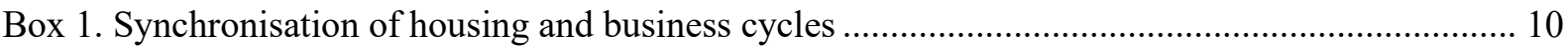

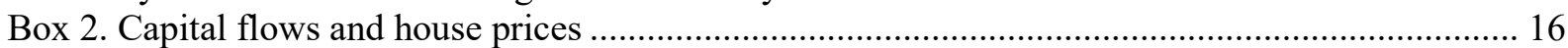

Box 3. Gauging land use policies from urban sprawl data ............................................................... 45 


\title{
Housing Markets and Macroeconomic Risks
}

\author{
By Maria Chiara Cavalleri, Boris Cournède, Volker Ziemann ${ }^{1}$
}

\section{Introduction and main messages}

1. Housing markets provide a sizeable contribution to economic activity. Fluctuations in house prices and residential investment can also be large, affecting the business cycle and amplifying shocks through balance sheet effects on households and lenders. Indeed, across most OECD economies, vulnerabilities in housing markets were either the trigger or a key amplifier of the sharp downturn during the global financial crisis.

2. House price fluctuations can be a source of risks and disruptions, but positive housing dynamics can also stimulate economic activity. Part of the recent recovery in output and consumption can be attributed to the stimulus provided by the sustained recovery of house prices following the corrections after the financial crisis, together with favourable income developments and financial conditions. Those countries that saw rapid recoveries in house prices following the crisis, such as the United States, the Netherlands and the United Kingdom, have also been those recovering swiftly from the recession.

3. House prices and output influence each other. House prices affect the credit market and, via this channel, the real economy. In addition to the direct effect of housing investment, much of the transmission of housing shocks to the rest of the economy happens via wealth and collateral effects (i.e. the financial accelerator effect) on consumption. The presence of wealth effects makes it possible that a prolonged period of house price increases (and hence of house values) could be perceived by households as a permanent increase in wealth, which can change their saving and consumption choices. Changes in house prices also have a direct impact on households' net worth, which in turn influences their borrowing capacity. The change in access to credit will then amplify the business cycle leading to more persistent and stronger effects on the economy.

4. The current situation, which is characterised by house prices approaching or exceeding pre-crisis levels in many countries, raises the question as to whether these price levels may be indicative of a possible impending correction. This study lays out first why

1. This report contributes to the OECD Housing Project. The authors are members of the OECD Economics Department. The Working Party No. 3 for the Promotion of Better International Payments Equilibrium discussed an earlier version of this paper. The authors thank members of the Working Party and in particular its Chair, Mr. Peter Praet (European Central Bank), for their feedback. The authors are indebted to Laurence Boone, Peter Hoeller, Luiz de Mello and Alain de Serres (OECD Economics Department) for their guidance and to Thomas Chalaux, Hermes Morgavi and David Turner (OECD Economics Department) for sharing the results of their probit models of severe downturn risk and advising us on their use. They would like to thank Aida Caldera Sanchez, Andrew Barker, Sebastian Barnes, Tim Bulman (OECD Economics Department) and Sebastian Schich (Directorate for Financial and Enterprise Affairs) for their comments. They express their gratitude to Sonya $\mathrm{Lu}$ (Georgetown University) for her work on the database of macro-prudential measures. The authors are grateful to Celia Rutkoski (OECD Economics Department) for editorial support. They can be reached at mariachiara.cavalleri@oecd.org, boris.cournede@oecd.org and volker.ziemann@oecd.org. 
the housing market matters for resilience (Section 2) and evaluates how OECD countries are situated in the housing cycle (Section 3). It then uses recently developed models to gauge the magnitude of medium-term downturn risks with a focus on the role of housing in this assessment (Section 4). Finally, the paper reviews the results of new empirical investigations to discuss how macroprudential and housing policies can prevent future build-ups of housing risks. ${ }^{2}$

5. The main messages are:

- House price developments and housing investment have varied considerably across and within countries since the global financial crisis.

- In many countries, households are more indebted now than at the onset of the crisis, but low interest rates currently relieve household budgets.

- Banks on average are better capitalised than ten years ago. Less regulated non-bank lending has become more important than before the crisis in a number of European countries. By contrast, it declined slightly from high levels in the United States and remained stable in Canada.

- A model developed to evaluate uncertainties around OECD economic projections allows estimating two year ahead downturn risks. This model, which was built by testing the predictive capacity of many variables, includes housing and credit developments as key leading indicators of downturn risks.

- Estimates for Canada, Germany, Sweden and the United States suggest real but limited (below 30\%) risks that these economies may experience a severe downturn over the medium term, with housing trends playing a significant role.

- Risks are estimated to be much smaller in the other countries covered by the model. However, there appears to be some non-negligible risk in France and Japan, linked to the upward trend in real house prices.

- Where risks are already elevated, monetary and fiscal policies provide the most appropriate instruments to confront housing-related risks that have already become high, as discussed in (OECD, 2019 $\left.{ }_{[1]}\right)$.

- Where risks remain contained, macroprudential, housing and tax policies can provide complementary tools which together can reduce the build-up of future housing risks:

- Loan-to-value ratios can be effective at containing the build-up of credit risk, and new evidence suggests that tighter loan-to-value ratios are linked with a lower risk of severe downturns.

- Caps on debt-to-income ratios hold promising potential but have been used seldom, which limits possibilities to assess their effectiveness on an empirical basis.

2. This paper is related and complementary to recent IMF work on housing (IMF, 2019 [31]): the IMF study documents downside risks to house prices, shows that house price risk helps predict financial crises and explores how macroprudential policies influence risks of housing downturns. The present report presents estimates of risks of severe downturns in output, which often emanate at least in part from housing and credit markets. It then presents empirical analysis of how macroprudential and housing-related policies influence the resilience of output. The results are mutually reinforcing, with both studies highlighting the benefits of macroprudential policies. 
- More demanding capital requirements are associated with more moderate output fluctuations and stronger recoveries after downturns.

- Higher taxation of housing (higher property taxes but also lower income tax breaks for housing) is linked with smoother housing cycles.

\section{Why does the housing market matter so much for resilience?}

6. Real house prices move in close step with the economic cycle (Figure 1). In the boom phase, strong labour markets, economic growth and abundant credit supply feed into high demand, which push up real house prices. House price increases raise households' collateral values and their net worth, which can in turn boost their consumption. Higher real house prices may lead to second-round effects as they may also create expectations of further price increases, feeding back into higher demand. A relaxation of lending standards and innovations in mortgage markets may further fuel house prices, a feedback loop that was at the centre of the global financial crisis (National Commission on the Causes of the Financial and Economic Crisis, 2010 $[2])$.

Figure 1. House prices and business cycles are tightly linked

Annual real percentage change, OECD average

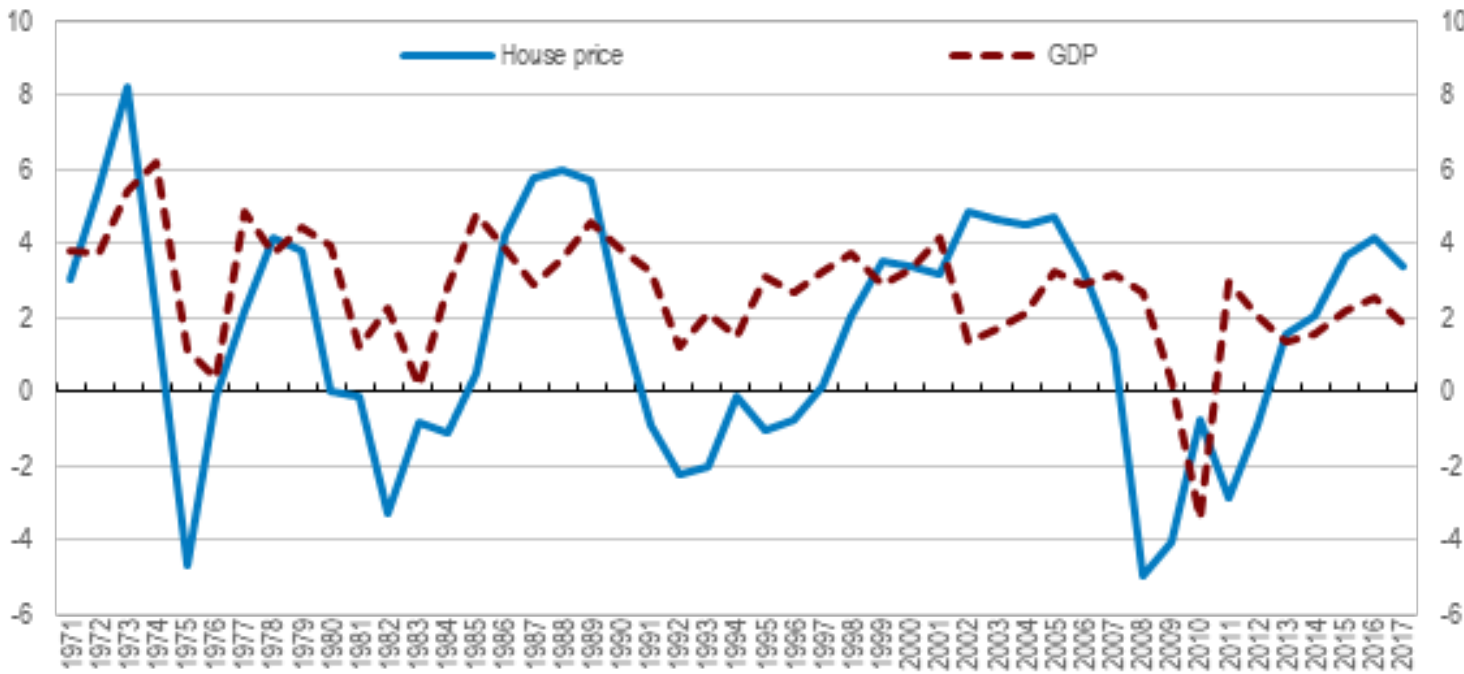

Source: OECD Economic Outlook database and OECD Analytical House Price database.

7. Whereas the underlying causes and triggers may differ, bust phases in housing markets are characterised by the opposite developments to the boom phase. First, house price drops lower collateral values, which in turn increase the losses that lenders face in the event of a default with implications for financial stability. Second, household wealth and the prospects of the construction sector are negatively affected, which tends to decrease spending. This reduces overall economic activity, leading to deteriorating macroeconomic conditions and a weakening of the economic outlook and fiscal balances. Housing downturns seem to have particularly damaging effects for inclusion and productivity because of the role of homes as collateral in loans to small and new firms (Lim, 2018 $8_{[3]}$; Davis and Haltiwanger, 2019 $\left.{ }_{[4]}\right)$. Housing downturns are therefore often associated with severe recessions (Figure 2). 
Figure 2. House price cycles have often been associated with severe recessions

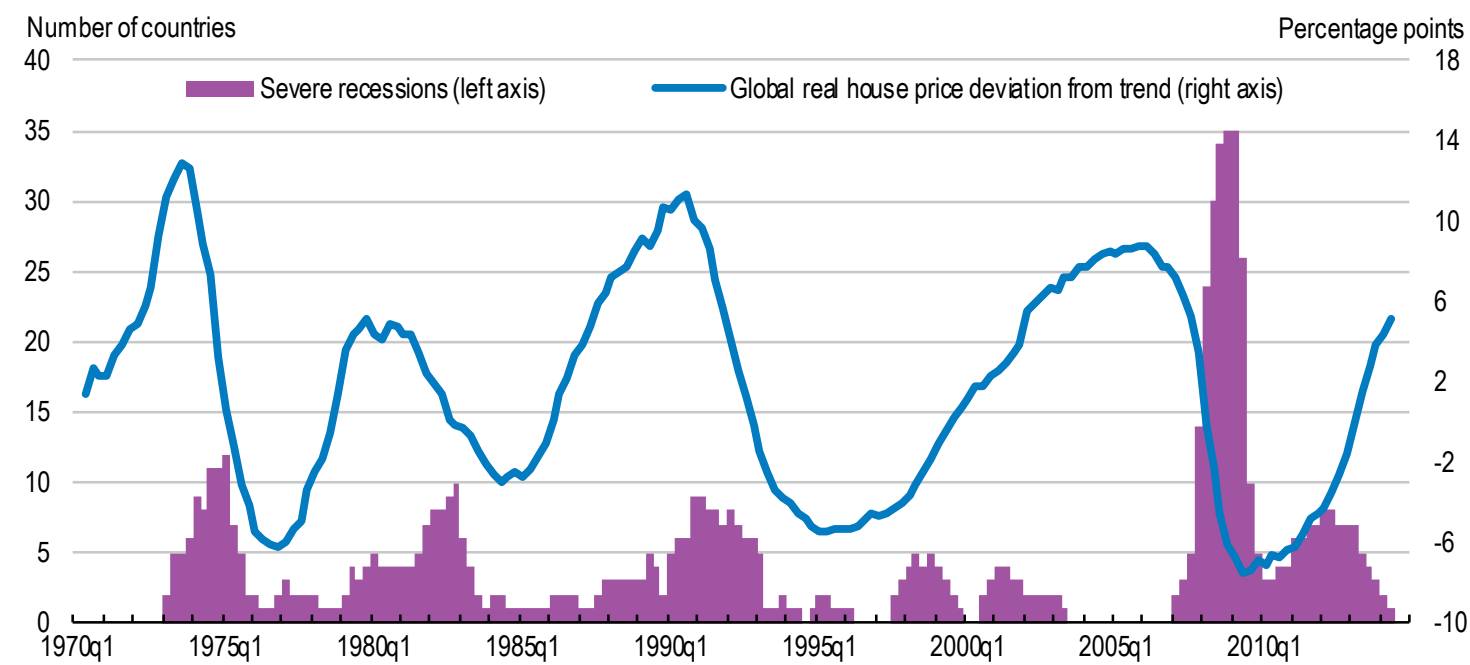

Note: The purple areas represent the number of countries identified as being in a severe recession (from peak to trough). The global real house price index is measured in deviation from a moving average. The global real house price index is a weighted average across OECD countries.

Source: (Hermansen and Röhn, 2017[5]).

8. Box 1 discusses the synchronisation of housing and business cycles. Annex A exhibits time series for cumulative 3-year growth rates of real GDP, real house prices and real housing investment for a sub-set of OECD countries. The evidence suggests that crosscorrelations between housing and business cycle variables differ across countries. Nonetheless, some strong patterns emerge. With the exception of Switzerland, residential investment is strongly correlated with GDP and mostly leading, notably in the United States. The duration of house price cycles is typically longer, but large corrections are often associated with an ensuing slowdown in real activity. 


\section{Box 1. Synchronisation of housing and business cycles}

To shed light on the synchronisation of housing markets and business cycles, Figure 3 depicts average movements of real GDP, the output gap, real house prices and residential investment around business cycles peaks (Panel A), deviation cycle peaks (Panel B), peaks in real house prices (Panel C) and peaks in residential investment (Panel D). Prior to business cycle recessions, residential investment is flat or falling (Figure 3, Panel A). In contrast, residential investment and real house prices move together with real output prior to turning points of the output gap, which is when growth falls below potential without necessarily trigging a recession (Panel B). In both cases, residential investment falls after the peak but, in line with real output, the fall is more substantial after business cycle peaks. Real house prices tend to lead real output when recessions occur but lag real output when the output gap peaks. This is partly due to the lag between peaks in output gaps and real GDP since growth falls below potential before becoming negative. In a nutshell, for the average recession, first the growth rate falls below potential then real house prices peak and then the recession kicks in.

Similar to real output, one can define turning points in the housing market using real house prices or residential investment. The results suggest that declines in real house prices trigger similar declines in residential investment (Panel C) but that declines in residential investment affect real house prices and output much less (Panel D).

Figure 3. Cyclical behaviour of output, house prices and residential investment
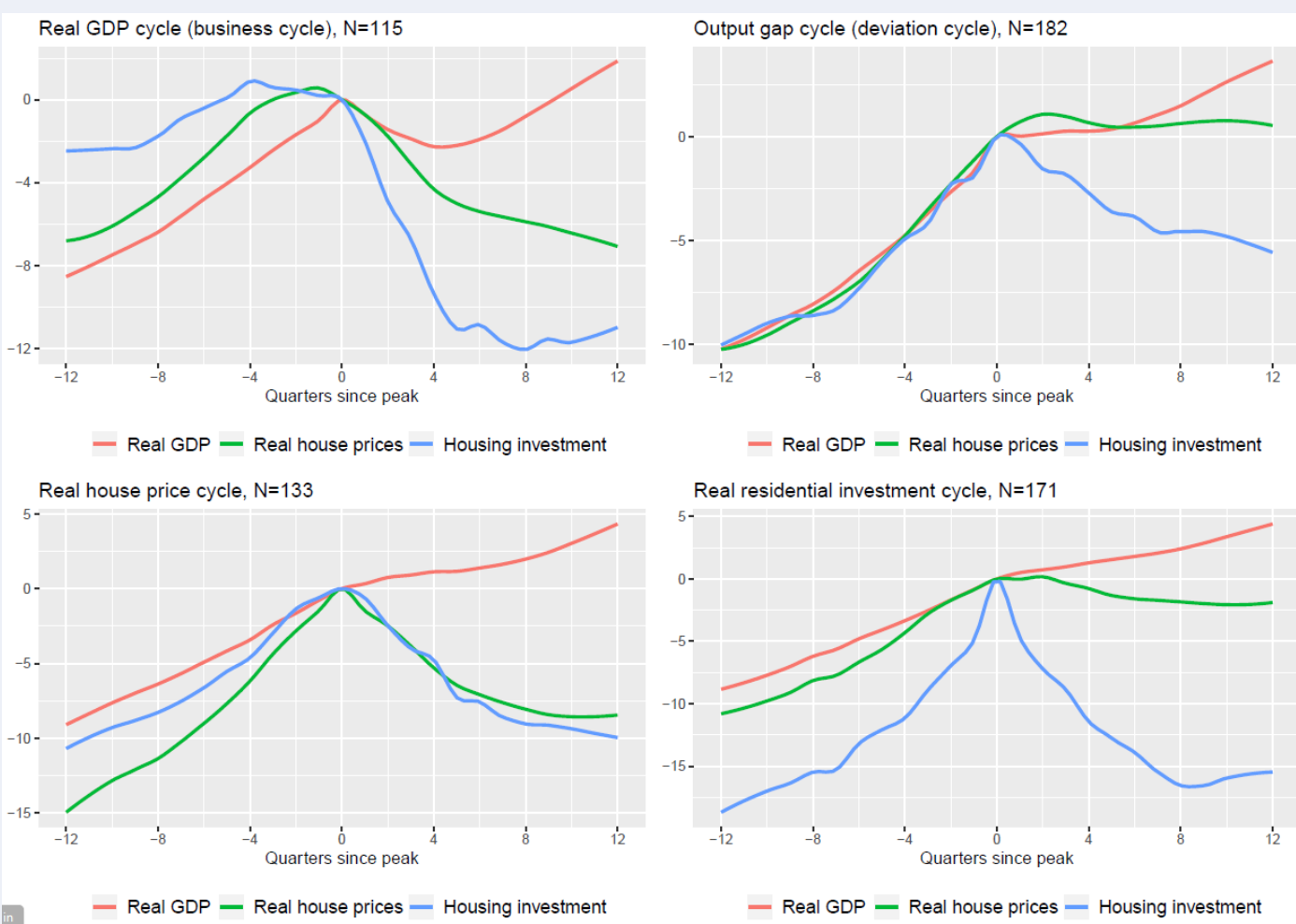

Note: Peaks are obtained using the Harding-Pagan (quarterly Bry-Boschan) business cycle dating procedure (Harding and Pagan, 2002[6]). N denotes the number of peaks.

Source: OECD Economic Outlook database and OECD Analytical House Price database. 


\section{Where do countries stand in the house price cycle?}

9. House price developments have been heterogeneous across countries since the onset of the global financial crisis more than 10 years ago (Figure 4). Some countries, such as Sweden, Canada, Germany or Switzerland, barely went through any correction during the crisis and have experienced strong real house price growth. In other countries such as France, Belgium or Japan, real house prices have been fairly stable since the crisis. However, many countries faced major corrections of more than $20 \%$ in real house prices. Some of them, such as the United States, the United Kingdom or the Netherlands have witnessed a bounce-back since 2012 and real house prices are approximately back to where they were before the crisis. In other countries such as Italy, real house prices remain depressed.

Figure 4. House price developments since the global financial crisis
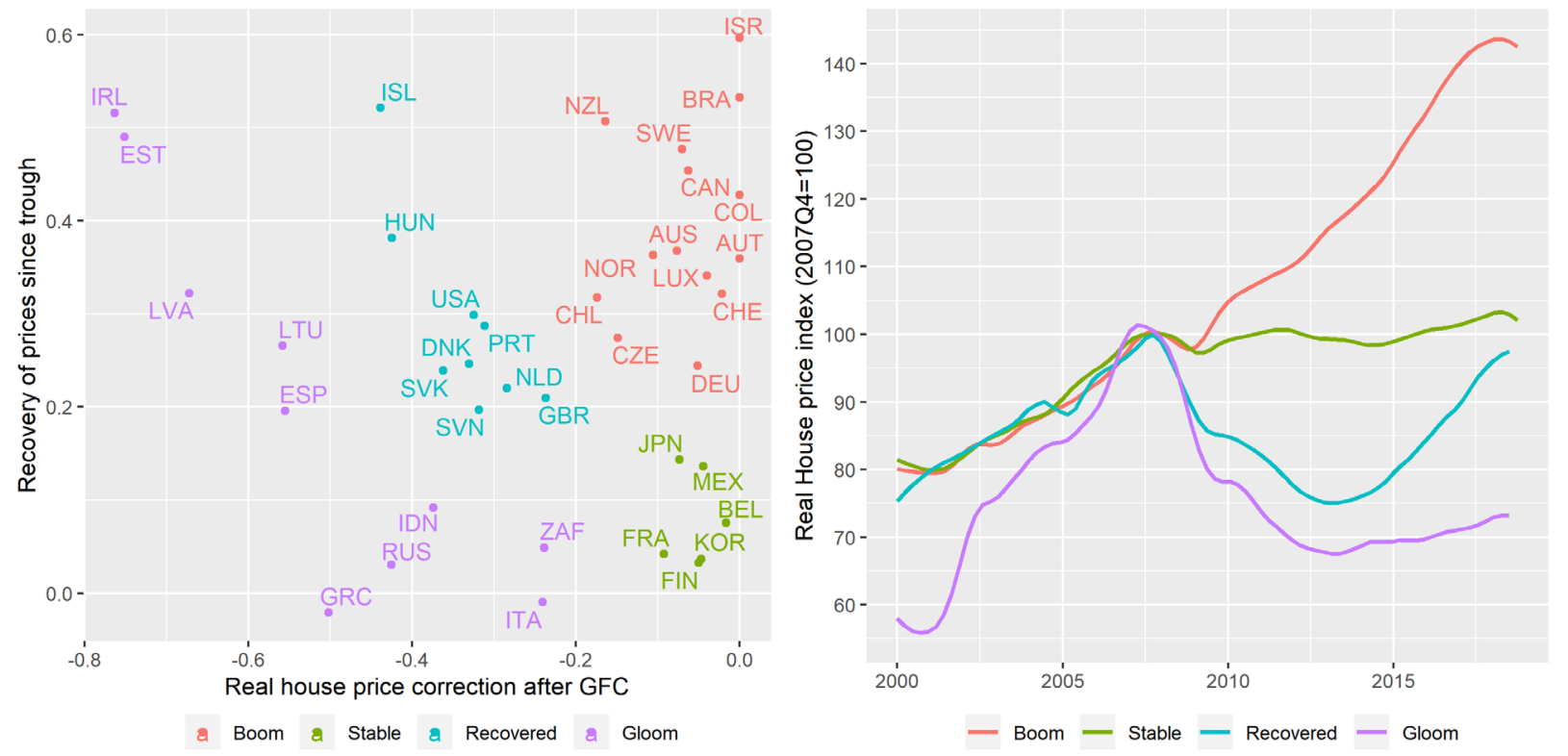

Note: The right panel depicts average price movements per country group using local regression techniques. "Boom" and "Stable" countries encountered a limited prices correction $(<20 \%)$ during the global financial crisis. The former witnessed sharp increases thereafter $(>20 \%)$ and the latter did not. "Recovered" and "Gloom" countries experienced a major real house price correction during the crisis $(>20 \%)$. The former benefited from an equally strong rebound while the latter did not.

Source: OECD Analytical House Price Database and authors' calculations.

10. A more granular look at the development of house prices points to considerable differences within countries. Notwithstanding initial differences in levels, in some countries such as France and Sweden, house price developments are broadly similar across regions while in other countries like the United Kingdom or the United States, interregional differences are large (Figure 5). Such large differences hint at local supply constraints in some areas rather than systemic inefficiencies of a country's housing sector that could be resolved by the use of tighter fiscal, monetary or macroprudential policies. On the contrary, where house prices rise strongly everywhere within a country, such as in Sweden, nation-wide policies could be more effective in managing housing demand and thereby relieve pressure on prices. 
Figure 5. Regional house price growth differences are stark in some countries

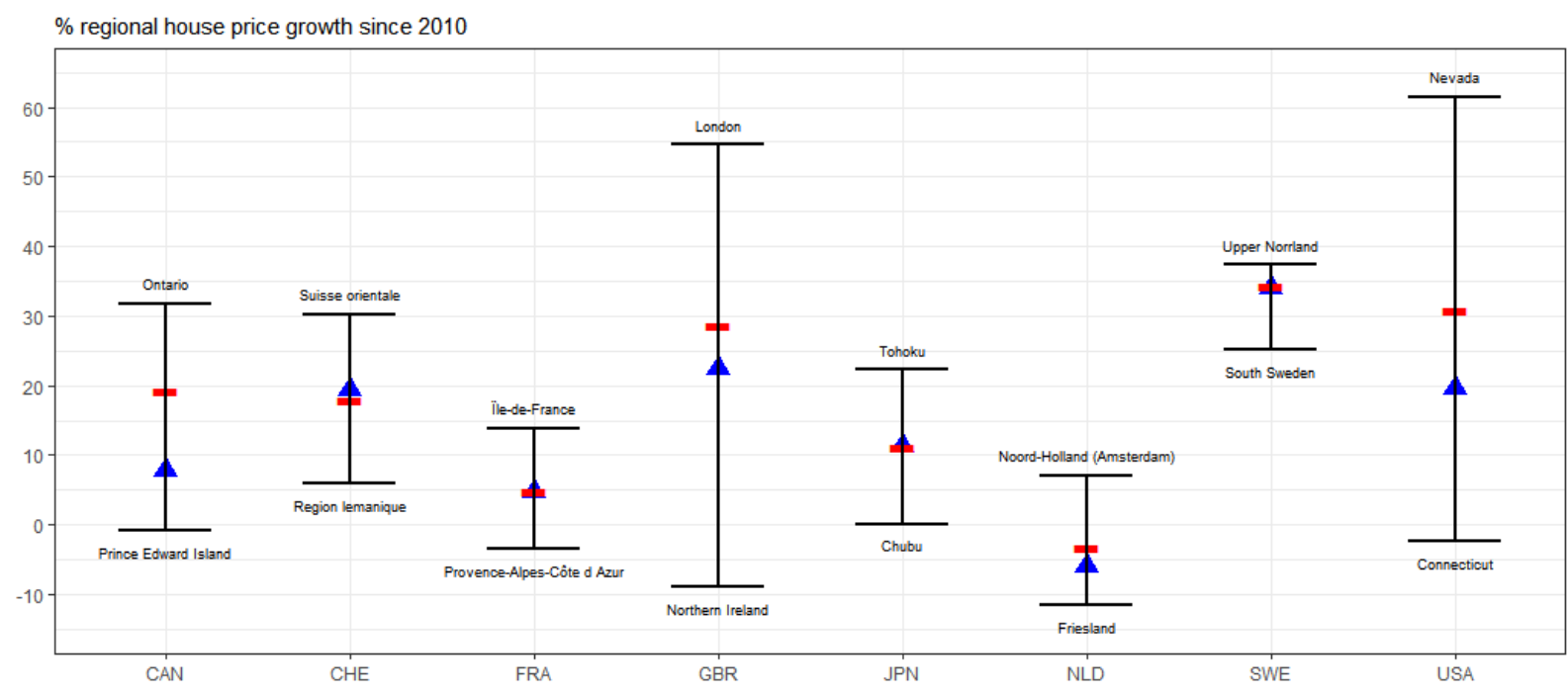

Note: Segment represents range of changes in nominal house prices across each country's regions (NUTS 1 administrative level). Whiskers denote the highest/lowest regional change since 2010. Blue triangles denote the median region, red bars the country aggregate.

Source: OECD Regional House Price Database (forthcoming).

11. The share of residential investment in GDP is now lower than at the onset of the global financial crisis in most countries (Figure 6), although there are substantial differences in terms of investment cycle amplitudes across countries. In the Netherlands, for instance, both the bust and the subsequent recovery of housing investment were more pronounced (bust of more than $50 \%$ until 2014 , followed by a recovery of more than $50 \%$ since) than in Belgium, where the correction and recovery of residential construction was moderate. Countries where house prices boomed after the crisis have often also experienced a surge in residential investment as a share of GDP. Prominent cases are Germany, Sweden and Canada. Switzerland is an exception, as housing investment has remained stable at a low level in international comparison despite strong increases in prices, suggesting strong obstacles to construction, which could emanate in particular from land use policy. Future OECD work will aim at comparing the responsiveness of housing supply to demand pressures across countries with a focus on the role of policies. 


\section{Figure 6. Housing investment}

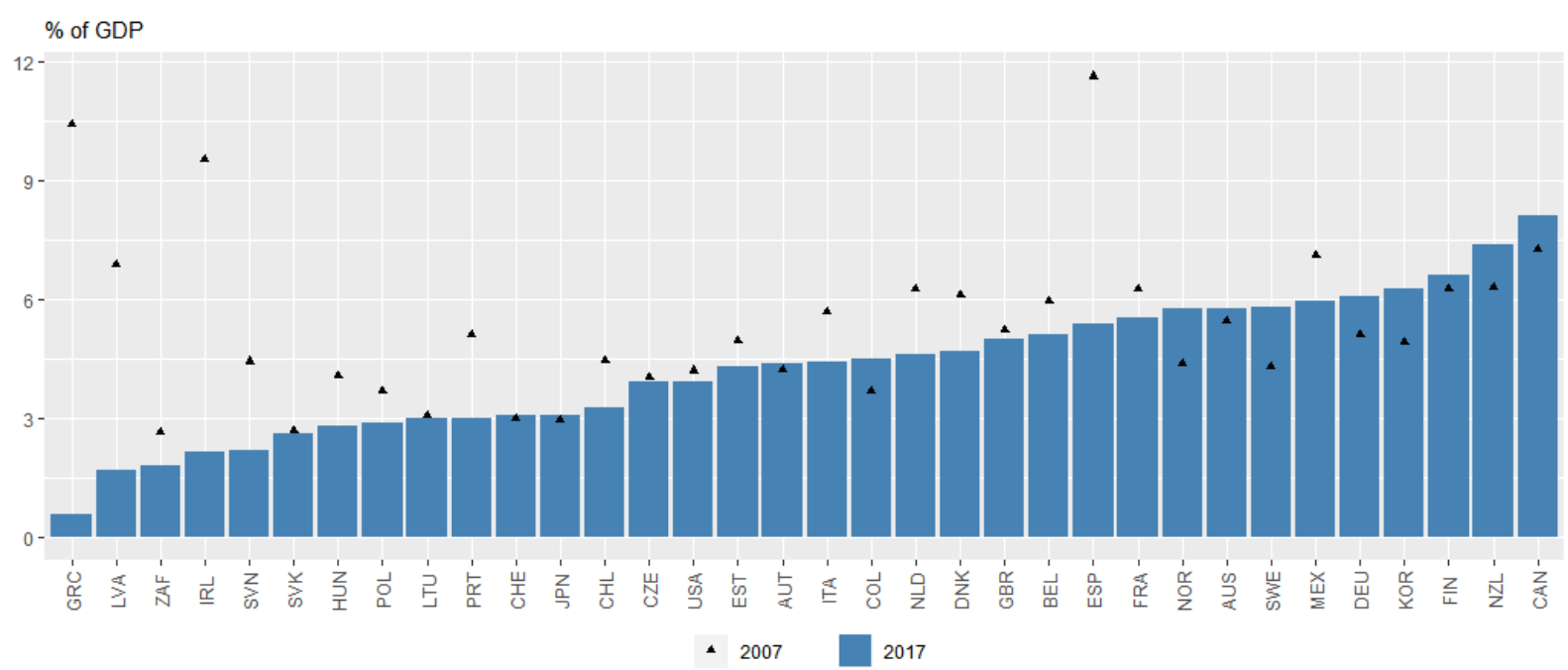

Note: Nominal residential investment as a share of nominal GDP is shown. Source: OECD Economic Outlook Database.

12. Excessive credit growth has often been a driver of financial crises. Over the past 10 years, mortgage lending as a share of household disposable income has risen substantially in a number of countries (Figure 7), notably Canada, Switzerland and Sweden, all of which have also experienced strong increases in house prices. In Germany, mortgage lending has remained low and even decreased a little as a share of disposable income despite the up-tick in housing investment. Historically low interest rates at present, however, have attenuated the pressure on household debt servicing.

Figure 7. Debt weighs less on households despite limited deleveraging in most countries
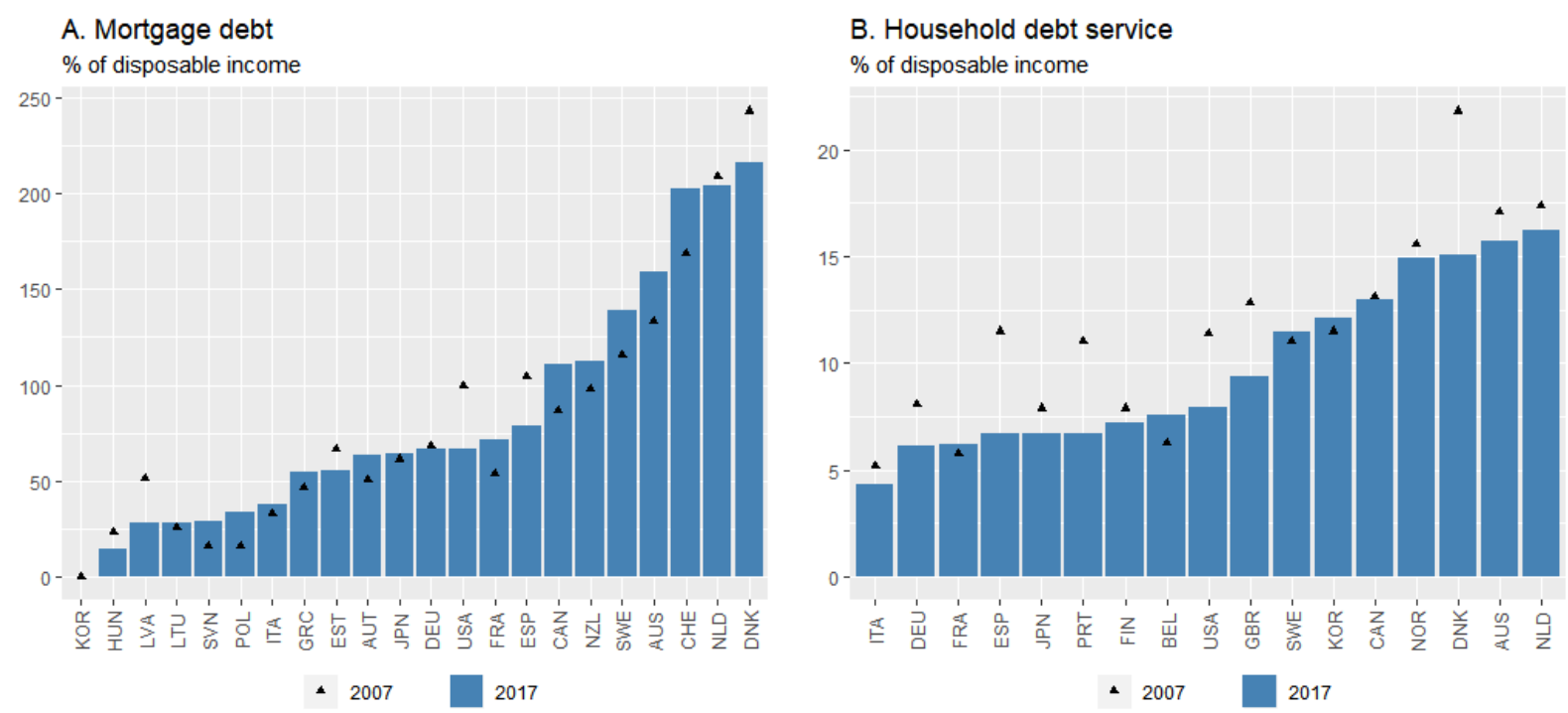

Source: OECD Resilience Database for Panel A and Bank for International Settlements for Panel B. 
13. Excessive leverage in the financial sector accompanied the massive increase in mortgage credit and the ensuing housing bubble in the mid-2000s. In the aftermath of the burst, bank balance sheets deteriorated considerably in many countries, which weighed on credit supply. More than 10 years later, banks are better capitalised overall (Figure 8), partly thanks to global initiatives that have tightened banking regulation including by increasing minimum capital requirements, limiting bank leverage and introducing countercyclical buffers (Basel III). Nonetheless, non-risk weighted capital ratios (leverage ratio, right panel) continue to be close to the required minimum backstop of 3\% in a number of countries. This situation for leverage may give cause for concern if, as in 2007-9, assets previously considered as warranting low risk weights turn out to be more vulnerable than anticipated.

Figure 8. Banks have more solid buffers
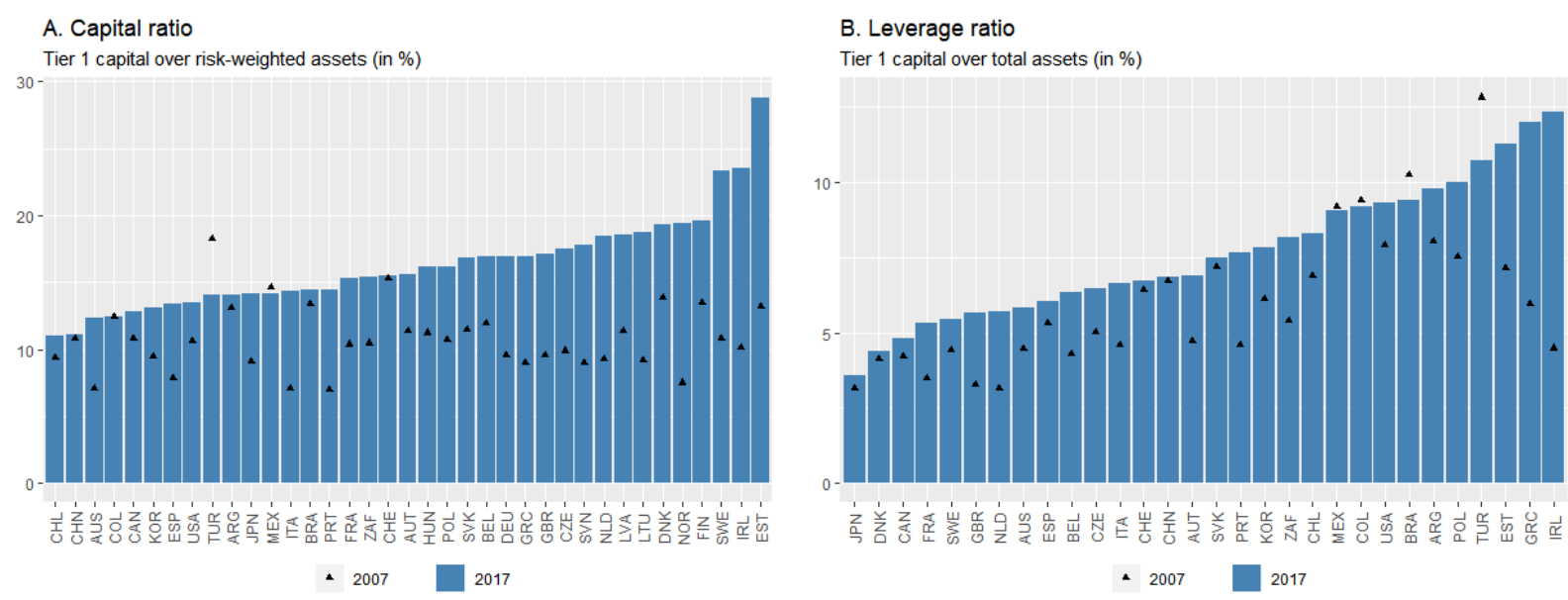

Source: OECD Resilience Database.

14. Partly because of banks' deleveraging and tighter supervision, credit has increasingly been channelled through non-banks since the global financial crisis, especially in Europe (Figure 9). The role of non-bank lenders in mortgage lending has become increasingly important in the Netherlands, while the share of non-bank lending in credit to households has also substantially expanded in Belgium (ECB, 2017 $7_{[7]}$ ). On the one hand, this development may be seen as worrying since non-bank lending and the associated securitisation were commonly identified as main drivers of the build-up of risk leading to the global financial crisis (National Commission on the Causes of the Financial and Economic Crisis, 2010[2]). On the other hand, non-bank lending alleviates some of the concerns about the propagation of shocks throughout the financial system to the extent that non-bank lenders are not as systemic as banks. 
Figure 9. More credit is channelled through non-banks

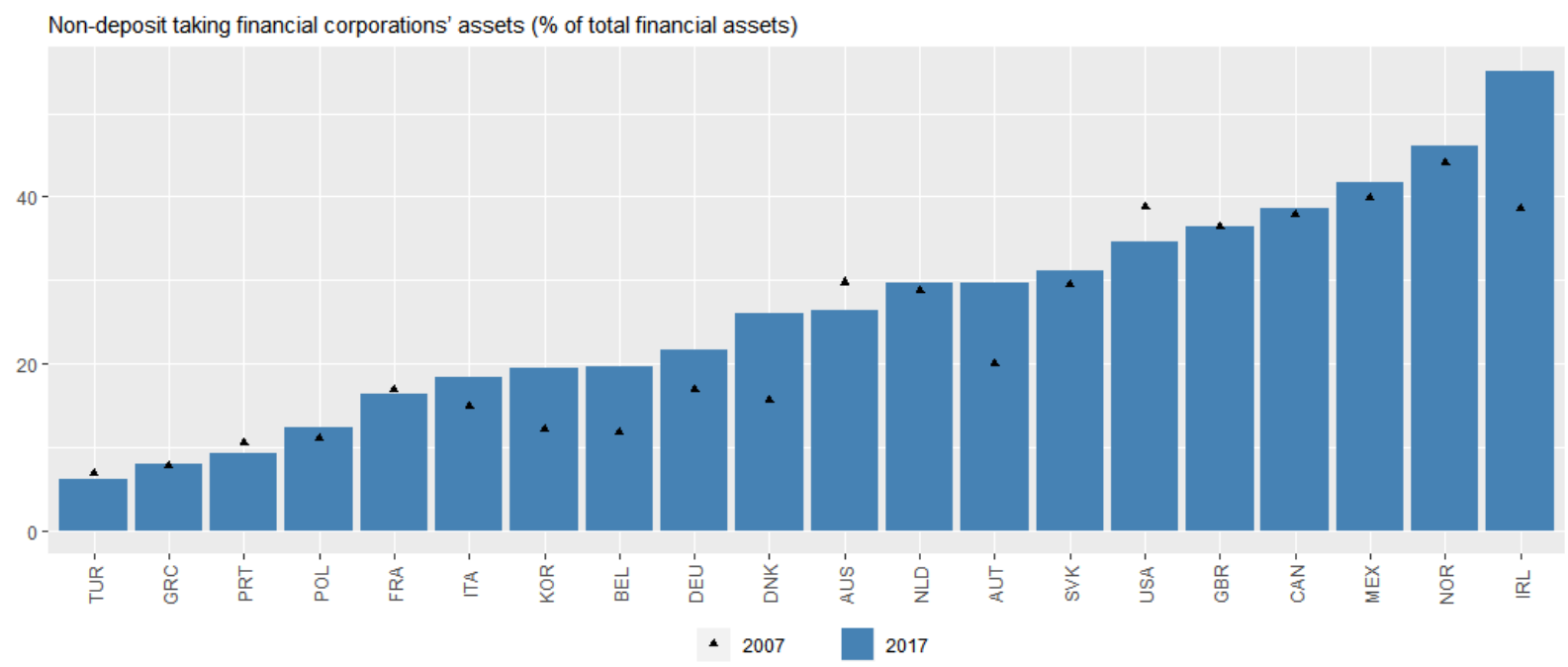

Source: OECD Resilience Database.

15. Concerns have emerged in some countries that foreign capital inflows may have a potentially destabilising influence on housing markets. The small number of existing estimates, however, suggests that the foreign share of house purchases and of the housing stock is small (Box 2). 


\section{Box 2. Capital flows and house prices}

The economic literature analysing the direct impact of foreign acquisitions on domestic house prices remains scarce and mostly country-specific.

There exists, however, cross-country evidence of a broad relationship between aggregate capital inflows and house prices. Capital inflows may raise asset prices through several channels: first, the increased demand for housing will have a direct effect on house prices; second, the increased money supply and liquidity because of the capital inflows, unless sterilized, will lead to higher asset prices. Finally, as capital inflows have an impact on economic activity, higher growth should push up house prices. A strong positive relationship has been found between current account deficits and house prices (Aizenman and Jinjarak, 2009 $\left.{ }_{[8]}\right)$, and between total capital inflows and house prices, notably in Asia (Tillmann, 2013 ${ }_{[9]}$; Kim and Yang, 2009 $\left.{ }_{[10]}\right)$. In the United States, capital inflows resulting from "savings-glut" type shocks appear to have a positive and persistent effect on house prices (Sá and Wieladek, $2015_{[11]}$ ). In addition, the impact of capital inflows on house prices appears stronger in countries with more developed mortgage markets and even more so where securitisation is allowed (Sá, Towbin and Wieladek, 2014 ${ }_{[12]}$ ).

There is also evidence of global housing cycles, with house prices becoming increasingly synchronised across countries and major cities (IMF, 2018 $\left.{ }_{[13]}\right)$. House price synchronisation is associated with looser global financial conditions (Alter, Dokko and Seneviratne, 2018 $\left.{ }_{[14]}\right]$.

While such studies have looked at aggregate effects of total capital flows, or the nexus between house price and business cycles, the direct impact of real estate cross-border flows in driving house prices is much more difficult to estimate. This is mainly due to the lack of data on real estate flows as well as to the variety of channels through which cross-border real estate investment can occur.

Nevertheless, as foreign acquisition of real estate is a concern in several countries, national statistical institutes have provided estimates of the share of foreign investment in housing. In Canada, the share of non-resident owned properties is estimated at $4.8 \%$ in Vancouver and $3.4 \%$ in Toronto (Gellatly and Morrissette, $2017_{[15]}$ ). In Australia foreign investment in real estate accounts for an estimated 5\% of housing sales (Kearns, 2017 ${ }_{[16]}$ ), while the figure is closer to $25 \%$ in key cities like Melbourne and Sydney (IMF, 2018 ${ }_{[13]}$ ). In New Zealand, only around 3\% of homes are bought by foreign buyers (Statistics New Zealand, $\left.2018_{[17]}\right)$.

Source: De Crescenzio and Lepers $\left(2019_{[18]}\right)$. 


\section{How large are current risks due to housing markets?}

16. Housing is an essential sector of the economy but can also be a source of vulnerabilities and crises. Recent OECD work (Turner, Chalaux and Morgavi, 2018 ${ }_{[19]}$ ) has developed country-specific probit models to assess the probability of future severe downturns using a wide array of macroeconomic and financial variables related to the business cycle. A severe downturn is defined as an episode in which GDP per capita falls cumulatively by at least 2 per cent. ${ }^{3}$ The risk of severe downturns is strongly related to developments in house prices and the credit, so that variables from these two categories feature prominently in the models.

17. The models, which gauge the risk of a severe downturn eight quarters ahead, are specified ${ }^{4}$ and estimated separately for eight ${ }^{5}$ OECD economies using data from as early as the 1970s. The models pick up domestic or international housing-related variables (house prices, their ratios to rent or income, and credit) in all the covered countries. The selection, sign and importance of housing-related variables vary across models (see Table F1 in Annex F for the selected variables and estimated probit coefficients). Overall, strong and sustained ${ }^{6}$ growth in real house prices or in the house-price-to-income ratio indicate heightened severe downturn risks two years ahead. Several models also identify share prices or the unemployment gap as risk predictors, while the US model also includes the yield curve in line with the literature (Estrella, Rodrigues and Schich, 2003 [20]).

18. The models perform well in identifying future severe downturn risks in GDP growth at the end of 2008 (Table 1). Out-of-sample forecasts using data up to the fourth quarter of 2006 anticipate a substantial risk (near or above 50\%) of entering 2009 with a severe downturn in France, Italy, Sweden, the United Kingdom and the United States. All these countries experienced GDP falls of about $4 \%$ or more during the crisis.

3. For Japan, the definition of a severe downturn takes trend growth, as measured by potential GDP per capita, as a reference point. This exception is justified on the basis of the high trend growth during the 1970s and 1980s, so that even a substantial and prolonged decline in growth in that period did not qualify as a severe downturn.

4. The choice of the explanatory variables varies across countries.

5. The United States, Japan, Germany, France, the United Kingdom, Italy, Canada and Sweden.

6 . Over the previous three to five years. 
Table 1. Severe downturn probabilities: The global financial crisis versus now

\begin{tabular}{|c|c|c|c|c|c|c|c|c|}
\hline & \multirow{2}{*}{$\begin{array}{c}\text { Risk of entering } \\
2009 \text { in a severe } \\
\text { downturn as of } \\
2006 \text { Q data }\end{array}$} & \multicolumn{3}{|c|}{ Peak-to-trough during the crisis (\%) } & \multicolumn{3}{|c|}{ Time to recovery to pre-crisis level } & \multirow{2}{*}{$\begin{array}{c}\text { Risk of entering } \\
2021 \text { in a severe } \\
\text { downturn as of } \\
2018 Q 4 \text { data }^{2}\end{array}$} \\
\hline & & House prices & $\begin{array}{l}\text { Housing } \\
\text { investment }\end{array}$ & GDP & House prices & $\begin{array}{l}\text { Housing } \\
\text { investment }\end{array}$ & GDP & \\
\hline CAN & 0.3 & -6.1 & -15.2 & -4.5 & 3 & 11 & 6 & 25.2 \\
\hline DEU & 0 & -5.8 & -12.9 & -6.9 & 17 & 8 & 8 & 28.2 \\
\hline FRA & 49.2 & -8.8 & -18.9 & -3.9 & 6 & 8 & 8 & 8.1 \\
\hline GBR & 93.2 & -20.0 & -43.7 & -6.3 & 9 & * & 7 & 0.0 \\
\hline ITA & 100 & -7.4 & -35.1 & -7.9 & * & * & 16 & 0.0 \\
\hline JPN & 5.4 & $(-)^{1}$ & -36.1 & -8.7 & $(-)^{1}$ & * & 17 & 13.9 \\
\hline SWE & 100 & -8.5 & -32.6 & -7.4 & 5 & 23 & 7 & 21.3 \\
\hline USA & 73.8 & -27.7 & -58.8 & -4.0 & * & * & 8 & 20.3 \\
\hline
\end{tabular}

Note: Peak-to-trough and time-to-recovery are based on turning points obtained using the Harding-Pagan (quarterly Bry-Boschan) business cycle dating procedure (Harding and Pagan, 2002[6]). Real output and prices are used. Peak-to-trough is in percentage points, time-to-recovery in number of quarters.

1. No turning point occurred in Japan's house prices during the global financial crises.

* denotes that the corresponding output or prices have not recovered as of late 2018.

2. Risk for Canada is estimated in 2021Q1, as of 2019Q1 data.

Source: Update of Turner et al. (2018) and authors' calculations.

19. The models are then used to gauge the risk of entering 2021 in a severe downturn (henceforth called medium-term severe-downturn risk) based on data up to the end of 2018 or the beginning of 2019. The baseline results use current data, while simulations are run for different housing market scenarios in order to highlight the role of this sector as a possible source of vulnerability.

20. The results are very heterogeneous across countries. The most exposed country according to the models is Germany, followed by Canada and Sweden. Risks are estimated to be low in France and Japan and negligible in the other economies. The role of housing varies across countries as follows, starting from highest to lowest estimated risk:

- House prices in the euro area have been markedly rising, which strongly influences the estimated probability (28\%) of medium-term severe-downturn risk in Germany. The relevance of the euro area house price variable for the German model presumably reflects the importance of the banking channel linking the economy to property markets in the rest of the monetary union. Germany is unique among the major countries in not including either domestic credit or domestic housing variables in the probit models at any horizon (Turner, Chalaux and Morgavi, $\left.2018_{[19]}\right)$. With flat euro area real house prices, the estimated downturn probability would lie below $10 \%$. A rising positive unemployment gap, suggesting signs of labour market overheating, is another factor behind the estimated downturn risk in Germany.

- The model for Canada estimates that the risk of a severe downturn over the medium term has been falling to $25 \%$ following a series of measures to tighten the macroprudential stance. The model includes US housing market developments, which account for contagion from the United States, where house prices have been rising in recent years. Buoyant domestic credit growth, largely fuelled by the domestic housing boom, was an additional factor that raised the odds of an upcoming economic downturn. The lagged impacts of the credit and housing channels are driving the estimated remaining risk. In a simulation which excludes 
the housing-related variables, the risk is estimated to be almost zero. The 2018 OECD Economic Survey of Canada already identified elevated house prices and household debt as key sources of financial and economic risk (OECD, 2018 $\left.8_{[21]}\right)$. A series of macroprudential measures have brought house price increases to a halt, with house prices declining in Vancouver and stabilising in Toronto. As a result, the estimated two-year ahead probability of a severe downturn has been steadily trending down (Figure F1 in Annex F).

- In Sweden, the estimated $21 \%$ probability of a severe downturn in 2021 reflects lingering effects of the past strong rises in household debt that accompanied the housing boom. The 2019 OECD Economic Survey of Sweden highlighted that, following macroprudential tightening, which in particular involved strengthening amortisation requirements, household debt has broadly stabilised while real house prices have drifted down since mid-2017 (OECD, 2019[22]).

- In the United States, the risk of a severe downturn occurring in 2021 is assessed at $20 \%$. The recent upswing in house prices and steep rise in their ratio over rents are driving this risk: in a scenario where housing market variables are kept flat, the estimated risk would be $6.2 \%$ (stemming from the tight labour market).

- In Japan, real house prices have been rising, but are still considerably below past peaks. As a result, the estimated risk of a severe downturn remains limited at $14 \%$.

- In France, the estimated low but non-zero (8\%) risk of a severe downturn in 2021 is predominantly driven by real house price increases.

- The model points to a negligible mid-term severe downturn risk in the United Kingdom and Italy:

- The case of Italy is largely similar to Japan's, as current house price levels are well below previous peaks.

- In the United Kingdom, house prices rose fast between the mid-1990s and the eve of the global financial crisis, but have risen less vigorously since then. One important caveat is that risks associated with Brexit fall outside the scope of this model.

21. The probit analysis reveals how housing, credit and labour markets shape severe downturn risks. Higher growth in domestic house prices or domestic credit raise the vulnerability to severe downturns in all the G7 probit models, with the exception of Germany (Table 2). Likewise, growth in international house prices or credit have a major impact on downturn risks in all G7 countries, except the United States. The effect of other variables, such as the yield curve or share prices, is country-specific. 
Table 2. Sensitivity of downturn probabilities to risk factors

Effect of a one standard deviation shock on the probability of a severe downturn at a horizon of 8 quarters

\begin{tabular}{|c|c|c|c|c|c|c|c|}
\hline & CAN & DEU & FRA & GBR & ITA & JPN & USA \\
\hline \multicolumn{8}{|l|}{ House prices and credit } \\
\hline Domestic house prices & & & & $19 \%$ & $12 \%$ & $4 \%$ & $9 \%$ \\
\hline Domestic credit & $8 \%$ & & $7 \%$ & & $10 \%$ & & \\
\hline International house prices & $13 \%$ & $10 \%$ & $9 \%$ & & & $20 \%$ & \\
\hline International credit & & & & $11 \%$ & $2 \%$ & & \\
\hline \multicolumn{8}{|l|}{ Other variables } \\
\hline Domestic share prices & & $7 \%$ & & $7 \%$ & & & \\
\hline International share prices & $6 \%$ & & & & & & \\
\hline Unemployment gap & $16 \%$ & $13 \%$ & & $7 \%$ & & & \\
\hline Yield curve slope & & & & & & & $-11 \%$ \\
\hline
\end{tabular}

Note: The underlying probit models are non-linear, so the numbers in this table report the average effect on the downturn probability of a one standard deviation increase in the explanatory variables at all points of the historical sample, which mostly begins in the 1970s. For the definition and functional form of the explanatory variables as well as details of the underlying equations see Annex F. The definition of 'international' variables differs between equations, referring to either OECD-wide, euro area or US developments.

Source: Turner et al. (2018) and authors' calculations.

22. Housing-related risks are present in countries not covered by the existing probit models of severe downturn risks. Sharp rises in house prices indeed entail potential risks to financial stability in the Netherlands (OECD, 2018[23] $)$. Similarly, the high exposure of the Swiss banking sector to the housing market through mortgages and outright ownership combined with the high level of house prices carries financial and macroeconomic risks (OECD, 2017 $[24]$ ). The housing market was identified as a moderate source of downside risk in Belgium in mid-2017 (OECD, 2017 $7_{[25]}$ ), since when house prices have risen by $5 \%$.

\section{How can housing-related policies reduce the build-up of macroeconomic risks and improve resilience?}

23. The analysis above highlighted the perils of housing bubbles and discussed the current situation. This section, which is based on Cournède, Sakha and Ziemann $\left(2019_{[26]}\right)$, first reviews what is known about the effects of policies on the interplay between housing markets and resilience and how countries are situated with respect to the policies that can be consistently measured across countries. It then presents the main lessons from new empirical analysis of the links between these policies and macroeconomic resilience. Annex B provides the definitions and sources of the data, while country averages of the policy indicators can be found in Annex D. For a full presentation of the analysis, see Cournède, Sakha and Ziemann $\left(2019_{[26]}\right)$

\subsection{What is known about the effect of macroprudential and housing policies on resilience?}

\subsubsection{Macroprudential regulation}

24. The main objective of macroprudential policy is to prevent financial threats to economic stability. Macroprudential policy aims at restraining the build-up of systemic 
risks by moderating credit and asset price cycles while ensuring the presence of sufficient buffers in the financial system. Achieving these goals is expected to reduce the misallocation of funds and thwart sharp corrections in financial markets associated with downturns in economic output (Richter, Schularick and Shim, 2018 ${ }_{[26]}$ ). Macroprudential policies aim at constraining and smoothing the financial cycle ("time dimension") and limiting spill-over effects of systemic risk through the interconnectedness of financial institutions ("cross-sectional dimension") (Borio, 2014 [27]).

25. A key advantage of macroprudential regulation is that it can be tailored to risks of specific sectors or loan portfolios. Macroprudential tightening need not entail a generalised reduction of economic activity, limiting the potential costs of policy intervention. By contrast, monetary policy serves as a powerful stabilisation instrument but may be more costly when imbalances are concentrated in specific sectors, such as housing (André et al., 2018 ${ }_{[28]}$; Bruneau, Christensen and Meh, 2018 [29]; Lane, 2016 [30] $_{\text {] }}$. Recent IMF work found that macroprudential instruments are more effective than monetary policy in reducing downside risks to house prices (IMF, 2019 $9_{[31]}$ ). Macroprudential instruments are also seen as more flexible and involving smaller implementation lags than most fiscal tools (Lim et al., 2011 $1_{[32]}$ ).

26. Macroprudential instruments can work on the side of borrowers or lenders. On the borrower side, the most frequently used tools include: ${ }^{7}$

- Loan-to-value (LTV) caps appear to be capable of moderating boom-bust cycles in general-equilibrium as well as agent-based models (Baptista et al., 2016 [33]; Laliotis and Población, 2016[34]; Kelly, McCann and O’Toole, 2018[35]; Funke and Paetz, 2016[36]; BIS, 2018 [37]; Kuncl, 2016 [38]; Ferrero, Harrison and Nelson, 2018 ${ }_{[39]}$ ). Tightening LTV caps could in the short term involve a trade-off between financial stability and social-inclusion objectives, by making it more difficult for young households with low savings to purchase homes (Gabarro et al., 2019[40]). In the medium to long term, however, more moderate house prices preserve the housing purchasing power of all households, including the young ones (Xiong and Mavropoulos, 2018 [41]).

- Debt-service-to-income ratios (DSTIs) require households to not pay more than a certain proportion of their income to service their housing loans. In some countries, DSTIs are based on total rather than only housing debt servicing costs.

- Loan-to-income ratios (LTIs), which limit the amount of debt to a certain fixed multiple of income, are less commonly used. They are equivalent to DSTIs for a given interest rate and repayment period but have the advantage of not becoming looser in times of booms when interest rates are low and banks offer more accommodative credit conditions.

27. The empirical literature looking at DSTIs and LTVs taken together has generally

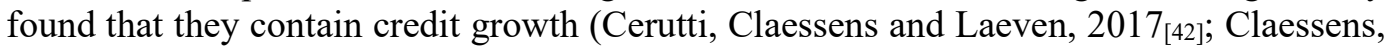
Ghosh and Mihet, 2013 $3_{[43]}$ ) and downside risks to house prices (IMF, 2019[31]). The effects of DSTIs and LTVs can, however, be expected to be weaker where households are less leveraged (Bednarek et al., 2019 $\left.{ }_{[44]}\right)$.

7. Other potential tools are restrictions on the use of variable-rate or foreign currency mortgages. Lack of data prevented their inclusion in the analysis. 
28. Typically used macroprudential policy tools working on the side of lenders include:

- A key policy lever is the minimum ratio of capital with which banks must hold for housing loans. The strength of this requirement is determined by the combination of minimum capital ratios and risk weights:

- Minimum capital ratios set floors for the ratios of different measures of capital (core equity, equity, core Tier I, Tier I, total capital) over risk-weighted assets.

- The empirical literature on the implications of risk weights is inconclusive. A case study for Israel found that a hike in risk weights contained house prices (Laufer et al., 2018 $8_{[45]}$ ). Using bank-level UK data, Aiyar, Calomiris and Wieladek $\left(2014_{[46]}\right)$ showed that unaffected lenders (foreign bank branches) offset one third of the impact of the tightening. Furthermore, Acharya, Engle and Pierre $\left(2014_{[47]}\right)$ consider that risk weights might lead to the build-up of financial risks because they encourage the build-up of exposure to other assets that are not deemed as risky but can still contribute to vulnerability.

- Other lender-side policy levers are minimum liquidity requirements (mostly the liquidity coverage ratio and net stable funding ratio), which aim to reduce liquidity mismatches between bank assets (including housing loans) and financing. Active use of these tools, which spread with the implementation of Basel III, is, however, too recent to have produced sufficient experience for their inclusion in the econometric analysis reported in the main text.

29. The literature is still split regarding the effect of macroprudential measures on average growth. Some cross-country estimates point to a trade-off between stability and long-term economic growth. For instance, Kim and Mehrotra $\left(2018_{[48]}\right)$, using a VAR model, find a negative effect of changes in macroprudential policies on output and inflation in the Asia-Pacific region. Similarly, Caldera Sánchez and Roehn (2016[49]), using quantile regression estimation, show that LTV caps reduce the median and upper part of the distribution of output growth. By contrast, Boar et al. (2017 [50] $)$ find that countries using macroprudential tools experience somewhat stronger and less volatile growth.

30. Macroprudential policies have been used more intensively since the global financial crisis (Figure 10). In the aftermath of the crisis, both capital requirements and LTV caps have been mostly tightened. Since 2012, the balance is more uneven for LTV caps, as many countries started to loosen regulation amid a depressed economic environment. 
Figure 10. Number of macroprudential policy interventions

A. Risk weighted capital requirements

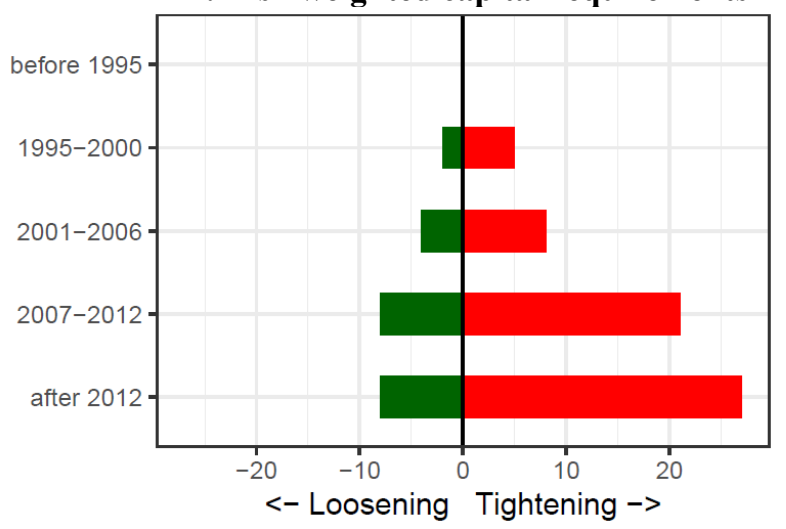

B. Loan-to-value caps

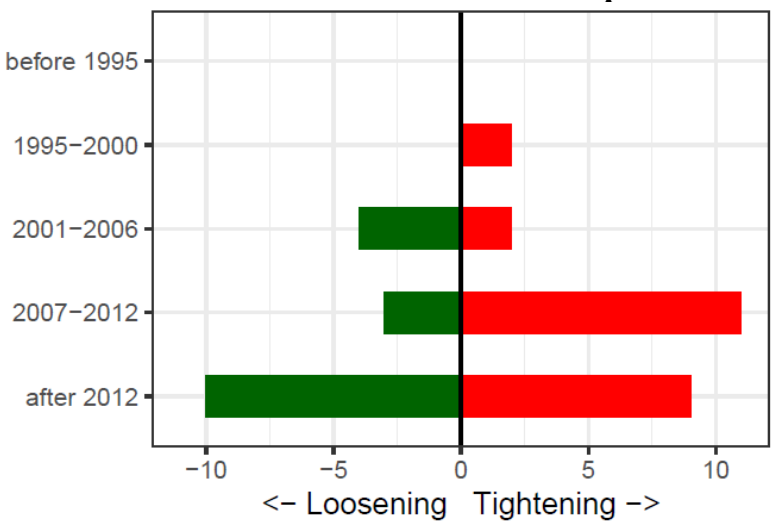

Note: Risk weighted capital requirements are the product of the minimum required Tier 1 capital ratio and the unweighted average of risk weights for mortgage loans with LTVs ranging from 50 to 130 (since Basel II, risk weights can differ by LTV). Loan-to-value caps refer to caps on mortgage loans for the purchase of the primary residence. Policy changes exceeding the average country-specific standard deviations qualify as policy interventions. The database comprises 19 countries for which LTV caps are registered at some point in time and 30 countries for which capital requirements are reported.

Source: Cournède, Sakha and Ziemann (2019[26]).

\subsubsection{Rental market regulation}

31. Rent controls and landlord-tenant rules have been devised for a variety of social and economic reasons, such as to provide affordable accommodation and balance the landlord-tenant bargaining power and to limit rent increases. Existing research has stressed potential negative efficiency consequences of limiting rent increases below market rates, including over-consumption of housing by tenants of rent-controlled apartments (Gyourko and Linneman, 1989 [51] $)$, misallocation of housing among tenants (Glaeser and Luttmer, $\left.2003_{[52]}\right)$; Bulow and Klemperer, $\left(2012_{[53]}\right)$ ), reduced construction activity (Glaeser and Luttmer, 2003 ${ }_{[52]}$ ), and neglect of maintenance of dwellings (Kholodilin, Mense and Michelsen, 2016 $\left.6_{[54]}\right)$.

32. They can also have implications for resilience. Past OECD research has shown that excessively tight rent regulations can affect the supply of new dwellings and maintenance of the existing rental housing stock and hamper the development of the rental market (Caldera and Johansson, 2013 [55]). This in turn, can lead to shortages of housing supply, exacerbating speculative housing bubbles and increases in household debt posing significant vulnerabilities for macroeconomic stability and economic growth (Hermansen and Röhn, 2017 $[5]$. Strict regulations in rental markets have also been found to reduce labour mobility (Andrews, Caldera Sánchez and Johansson, 2011 $1_{[56]}$ ). By preventing workers from moving to take up jobs, housing bottlenecks could lead to higher unemployment and increase the duration of downturns after an economic shock. Moreover, by hampering the reallocation of labour across firms, they could hold back productivity growth (Adalet McGowan and Andrews, 2015 $\left.{ }_{[57]}\right)$. Lux and Sunega $\left(2012_{[58]}\right)$ found with Czech data that tenure security negatively affects the decision to move for work-related reasons in the event of unemployment. The evidence is not conclusive, however, as Barceló $\left(2006_{[59]}\right)$ found no statistically significant effect of tenure security on the behaviour of unemployed workers in Spain. 
33. Yet, due to incomplete markets, in the absence of rent control, many tenants are unable to insure themselves against rent increases. Moreover, individuals may not be able to easily cope with local rent increases by moving to a cheaper location (Metcalf, 2018 ${ }_{[60]}$ ). However, if long-term tenants have developed neighbourhood-specific capital, such as a network of friends and family, proximity to one's job, or schools, then these tenants face large risks from a steep rent increase. A study by Diamond, Mcquade and Qian (2018[61]) highlights the trade-off between equity and efficiency: rent control initially brought large estimated benefits to older, low-income and minority households; however, in the long run, landlords lowered the supply of rental housing and shifted housing supply towards more expensive housing aimed at higher income individuals.

34. Starting in the mid-1970s, rent control has been liberalised in many countries, a process that came to an end in the early 2000s Figure 11, Panel A). Tenure security, on the other hand, has barely changed on average over this period but seen a rise in dispersion as some countries have tightened while others have loosened restrictions. Since the beginning of the 2000 s, the few registered policy actions where directed towards deregulating tenure restrictions.

Figure 11. Number of changes to rental regulations
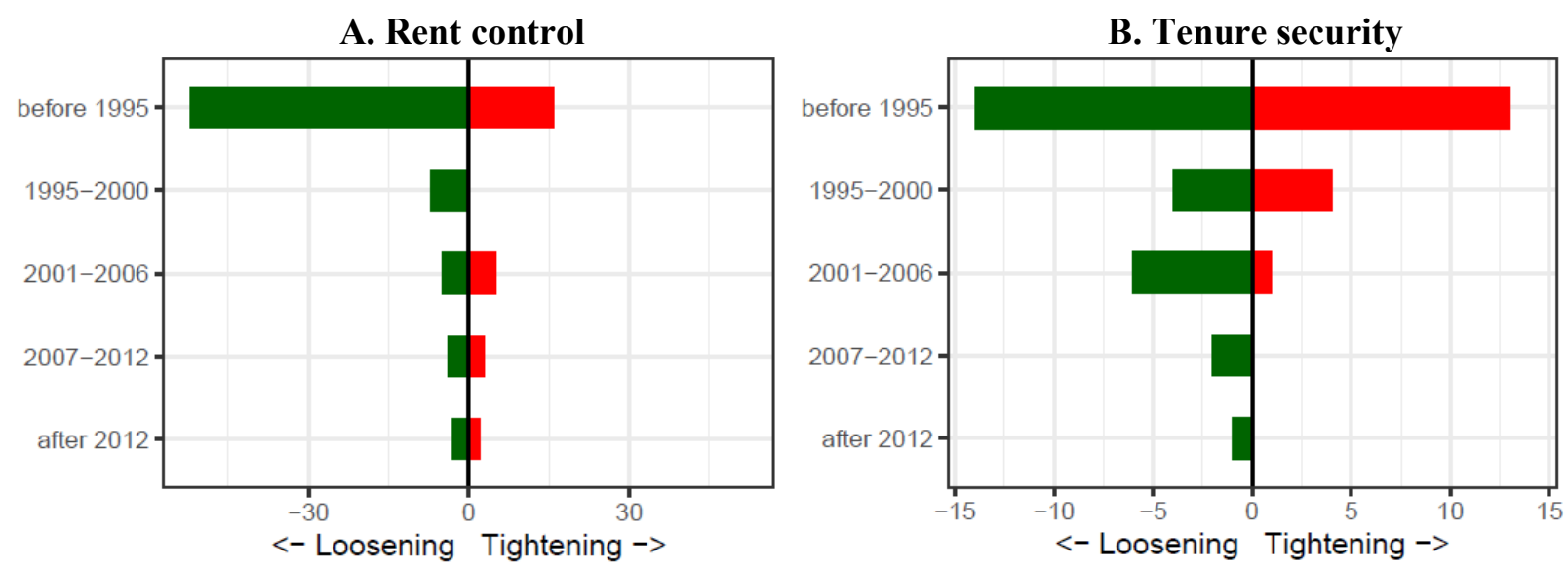

Note: Only large policy changes, e.g. those that exceed the average country-specific standard deviation qualify as policy interventions.

Source: Kholodilin, K. (2018), "Measuring Stick-style Housing Policies: A Multi-country Longitudinal Database of Governmental Regulations", DIW Berlin Discussion Paper, No. 1727 and Cournède, Sakha and Ziemann (2019[26]).

\subsubsection{Property taxation}

35. Stamp duties slow down house price booms by reducing the expected return on speculative house purchases. In normal times, higher stamp duties could thus reduce housing transaction volumes (Davidoff and Leigh, 2013 [62]). In particularly buoyant market conditions, however, these costs may lose much of their capacity to slow down the market: this would occur when expectations of house price appreciation become large enough to overcome the hurdle created by stamp duties and other transaction costs (Muellbauer and Murphy, 1997[63]).

36. In addition to their possibly complex effects on housing boom-bust cycles, transaction costs entail negative impacts on economic activity and well-being. Higher transaction costs lead to a lock-in effect, which is negative for reallocation in the labour 
market and also makes it more difficult for households to accommodate changes in housing preferences (Goodman and Mayer, 2018 [64]; Hilber and Lyytikäinen, 2017[65]).

37. By contrast, recurring property taxes should be broadly neutral with respect to the cyclical behaviour of housing markets and economic resilience. Their main effect should be to reduce the size of the housing market, by making housing more expensive, without affecting the dynamics of the market. From a broader perspective, recurring property taxes contribute to the stability of public finances, as their revenue is not tied to the cycle, and improve long-term economic performance, as they are less distortive than other taxes (Akgun, Cournède and Fournier, 2017 $\left.{ }_{[66]}\right)$.

38. New OECD measures allow gauging the combined weight of all tax instruments with relevance for housing, including personal income taxation, through marginal effective tax rates (METR) on owner-occupied and rental housing (OECD, 2018[67]). The METRs are derived as the difference between the pre and post-tax rates of return of a marginal investment divided by the pre-tax rate of return of that investment where the post-tax real rate is the minimum rate of return necessary to make the investment worthwhile. METRs are calculated for several saving vehicles including owner-occupied and rental property. Taxation of owner-occupied properties is typically lower as imputed rents are often not taxed and interest payments deductible. For the supply of housing, both types of investment matter. Figure 12 shows both, here assuming that the property is fully equity-financed.

Figure 12. Marginal effective tax rates for residential property

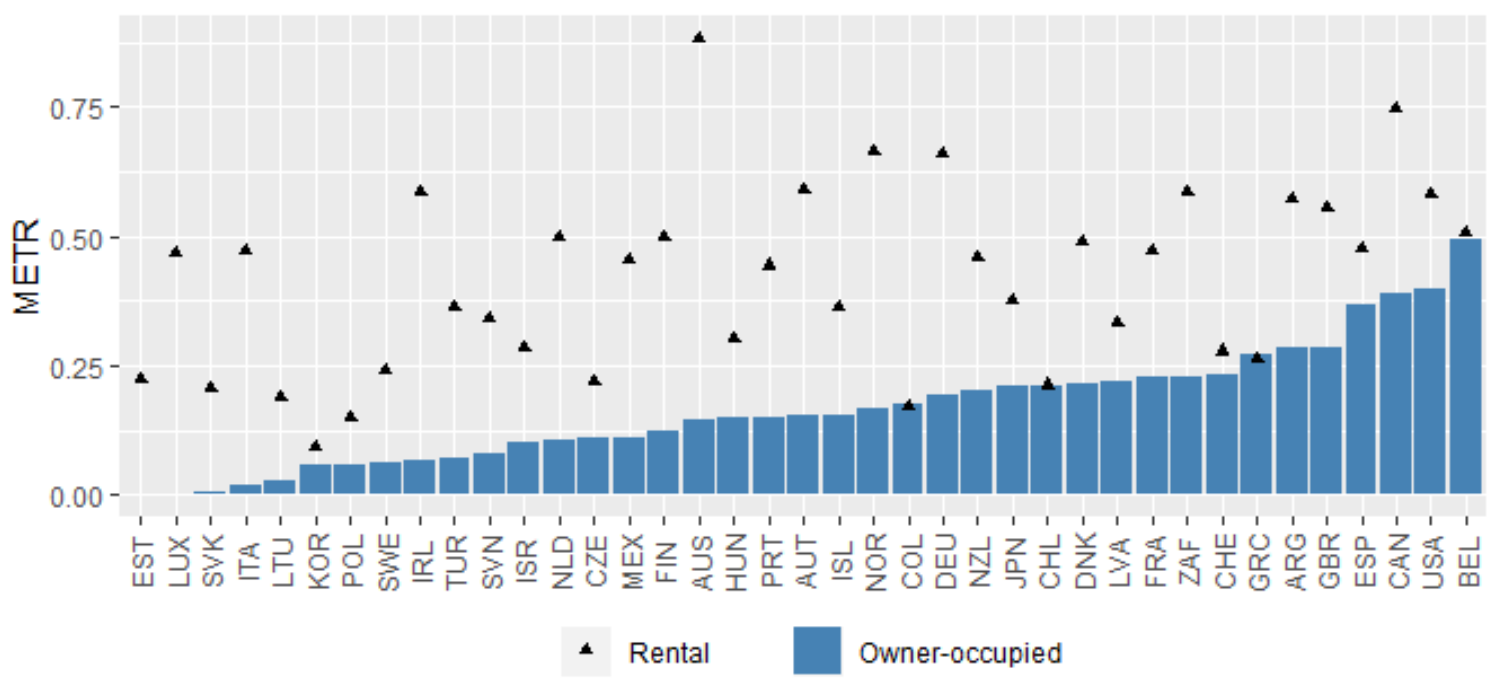

Note: METR stands for marginal effective tax rates.

Source: Taxation of Household Savings (OECD, 2018[67]).

\subsubsection{Public support for housing}

39. The public provision of social housing should in principle contribute to economic and especially social resilience (Salvi del Pero et al., 2016 $6_{[68]}$ ). One channel with implications for resilience is that the availability of social housing reduces the need for more vulnerable and low-income workers to take risky housing loans in order to buy a home. Past OECD work has highlighted that low-income workers are more exposed than others to job-loss risk (Garda, 2016[69]). The US subprime mortgage crisis has highlighted the macroeconomic risks associated with over-borrowing by low-income households (Griffin, Kruger and Maturana, 2018[70]). Furthermore, social housing can also involve 
important economic and social side effects, including hurting tenants' labour-market prospects, when, as often, the right to social housing is not transferrable to a different place (OECD, 2011 $1_{[71]}$; Barceló, 2006 [59]). The OECD's Affordable Housing Database provides indicators to measure the extent of public support for housing-related expenses (Figure 13).

Figure 13. Public support for housing expenses
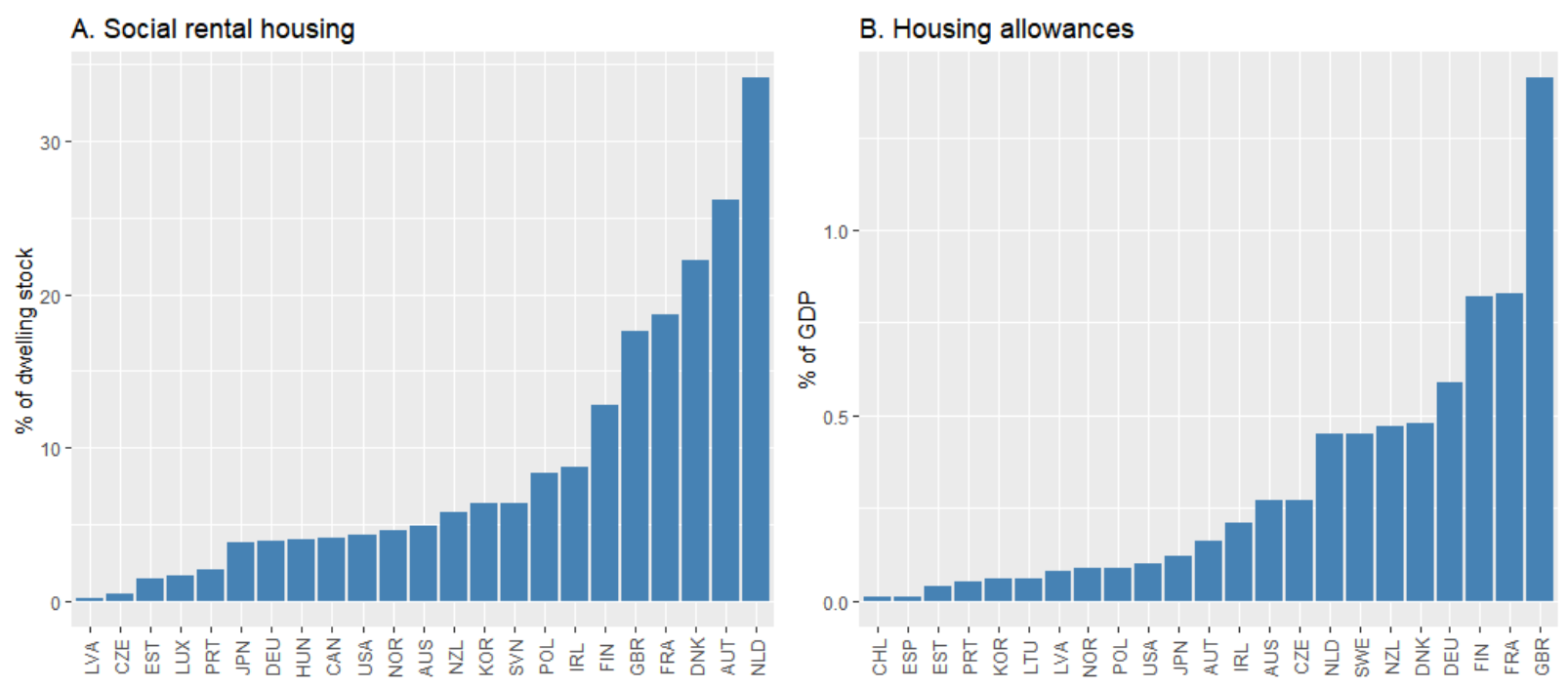

Source: OECD Affordable Housing Database.

\subsection{Framework for the analysis of macroprudential and housing policy effects on resilience}

40. Recent OECD analysis has investigated how housing-related economic policies, including macroprudential policy, taxation and housing market regulation shape economic resilience. This analysis assesses how housing-related policies can affect the build-up of vulnerabilities, reduce the severity of crises and foster an economy's capacity to recover from crises. Figure 14 lays out a simple conceptual framework for the analysis by considering both ex-ante resilience (vulnerability to shocks) and ex-post resilience (resistance to and recovery from shocks). The analysis relates these resilience outcomes to policy drivers. This section provides a brief summary of the main results, while highlighting their policy implications. A detailed presentation of the analysis is available in Cournède, Sakha and Ziemann $\left(2019_{[26]}\right)$. 
Figure 14. A resilience framework for housing-related shocks

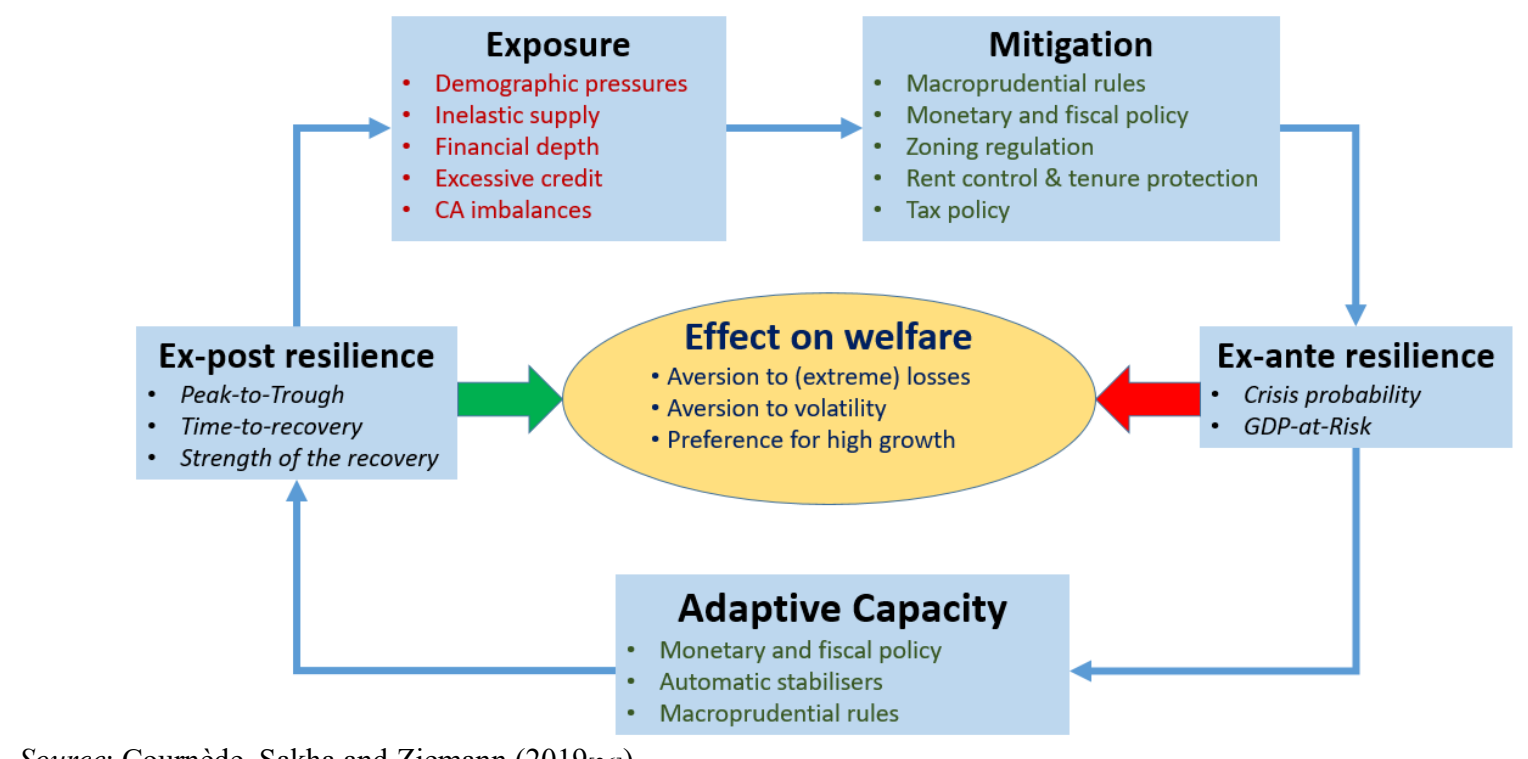

Source: Cournède, Sakha and Ziemann (2019[26]).

41. The functioning and characteristics of housing markets differ considerably across countries and so do related policies. The global financial crisis has triggered a wave of policy innovations many of which target the housing market directly. In particular, macroprudential policies have emerged as a widely used means of leaning against credit bubbles and enhancing financial stability. As discussed above, housing-related policies can also have an influence. The empirical analysis considers the following ones: property taxation, rental market regulation (rent control and tenure protection), housing support (social housing and housing subsidies) and zoning regulations (Annex C). The empirical analysis follows the framework: it focuses first on ex ante and then on ex post resilience. Table 3 shows resilience indicators for the period 1990-2017, for cycles in de-trended quarterly growth rates of real GDP. These indicators show marked variation, especially regarding crisis probabilities and the average magnitude of busts (peak-to-trough), which suggests a possible role for country characteristics and policies.

42. The guiding principle behind the empirical analysis is to overcome the limited availability of policy indicators by using a set of resilience measures for outcomes and an array of empirical methods. Indeed, for each individual outcome area, the analysis can only go so far before being constrained by the limited availability of policy indicators for macroprudential measures (mostly used recently), effective marginal tax rates on housing assets (one cross-section) and proxy for land use restrictions (one cross section). Instead, the investigation cross-checks the results across different outcome indicators, for which the method is chosen that makes the best use of the available data. 
Table 3. Resilience indicators, 1990-2017

\begin{tabular}{lcc|ccc}
\hline & \multicolumn{2}{c|}{ Ex-ante resilience } & \multicolumn{3}{c}{ Ex-post resilience } \\
\hline & $\begin{array}{c}\text { GDP at risk } \\
(\text { Q5 })\end{array}$ & $\begin{array}{c}\text { Crisis } \\
\text { probability }\end{array}$ & $\begin{array}{c}\text { Peak-to- } \\
\text { trough }\end{array}$ & $\begin{array}{c}\text { Strength of } \\
\text { recovery }\end{array}$ & $\begin{array}{c}\text { Number of } \\
\text { peaks }\end{array}$ \\
\hline BEL & -0.9 & 3.6 & -1.7 & 1.1 & 9 \\
CAN & -1.1 & 4.5 & -2.4 & 1.1 & 8 \\
CHE & -1.0 & 3.7 & -2.3 & 1.6 & 8 \\
DEU & -1.3 & 6.3 & -2.8 & 0.9 & 9 \\
FRA & -0.7 & 2.7 & -2.1 & 1.3 & 6 \\
GBR & -0.9 & 4.5 & -1.5 & 1.3 & 10 \\
ITA & -1.1 & 3.6 & -2.9 & 1.3 & 7 \\
JPN & -1.4 & 7.1 & -3.6 & 1.8 & 9 \\
NLD & -1.0 & 2.7 & -3.1 & 1.3 & 7 \\
SWE & -1.2 & 6.3 & -4.0 & 3.5 & 5 \\
USA & -1.1 & 4.5 & -2.3 & 1.4 & 7 \\
\hline
\end{tabular}

Note: Based on de-trended growth rate of real GDP from 1990 to 2017. Crisis probability denotes the probability of experiencing a cumulative two percentage point decline over two consecutive quarters. Q5 denotes the $5^{\text {th }}$ percentile of the distribution of de-trended real GDP growth. Busts refer to periods leading from a peak to a trough. Peaks are obtained using the Harding-Pagan (quarterly Bry-Boschan) business cycle dating procedure (Harding and Pagan, 2002[6]). Strength of recovery denotes growth over $n$ quarters, $n$ being the duration of the preceding bust period. Duration is in quarters, all other indicators are in percentage points. For ex-post resilience indicators, the table shows averages over observed cycles.

Source: Cournède, Sakha and Ziemann (2019[26]).

\subsection{Policies and ex-ante resilience}

43. GDP-at-risk, the first component of ex-ante resilience, is linked to macroprudential and housing policies using quantile regressions. Quantile regressions are run to identify which variables have an influence on the lower tail ( $5^{\text {th }}$ percentile) of the GDP quarterly growth distribution. Similar to Caldera Sánchez and Roehn $\left(2016_{[49]}\right)$, the empirical analysis uses Canay's $\left(2011_{[72]}\right)$ two-step approach to estimate quantile regressions with fixed effects. The panel quantile regression estimation takes the following form:

$$
\begin{gathered}
Y_{i t}=P O L^{\prime}{ }_{i t} \beta_{\theta}+X^{\prime}{ }_{i t} \gamma_{\theta}+v_{i}+\mu_{i t} \\
\text { with Quant }\left(Y_{i t} \mid P O L_{i t}, X_{i t}\right)=P^{\prime} O L^{\prime}{ }_{i t} \beta_{\theta}+X^{\prime}{ }_{i t} \gamma_{\theta}
\end{gathered}
$$

where $Y_{i t}$ is the quarter-on-quarter demeaned GDP growth rate for country $i$ at time $t$. $P O L^{\prime}{ }_{i t}$ is a vector of explanatory variables including housing and macroprudential policies for country $i$ at time $t$, while $X_{\mathrm{it}}$ is a vector of usual control variables for growth regressions. $\beta$ is the vector of parameters of interest, and $\mu_{i t}$ is a vector of residuals. Quant ${ }_{\theta}\left(Y_{i t} / X_{i t}\right)$ identifies the $\theta$ th conditional quantile of $Y$ given $X$ (Cournède, Sakha and Ziemann, $2019_{[73])}$.

44. Severe downturn probability, the second component of ex-ante resilience, is related to the same set of policies using probit regressions. Severe downturns are periods during which GDP per capita declines by 2 per cent or more, as identified by Turner, Chalaux and Morgavi $\left(2018_{[19]}\right)$. The probit relates a dummy variable for severe downturn events in country $i$, in year $t$, to lagged macroprudential and housing policies $P O L$ as well as the same controls as in [1]:

$$
\operatorname{Probit}\left(p_{i t}\right)=\beta_{1}(\mathrm{~L}) P O L_{i t}+\gamma X_{i t}+\delta_{i}+\varepsilon_{i t}
$$


45. The results point to a link between tighter macroprudential measures (loan-to-value caps and capital requirements) and lower severe-downturn probabilities (Table 4, Column 2). This result is in line with the literature, which finds a moderating effect of macroprudential measures on the build-up of housing booms and credit risk (Cerutti, Claessens and Laeven, 2017[42]; Claessens, Ghosh and Mihet, 2013 [43]; Alam et al., $\left.2019_{[74]}\right)$. This reduced probability of crises is not matched by a reduction in GDP at risk, the lowest $5 \%$ of the distribution of growth outcomes, as house price booms and credit bubbles typically build up slowly and burst with a protracted downturn (rather than frequent occurrences of very weak GDP growth).

46. A significant relationship is also found between rental market regulations and ex ante resilience indicators (Table 4). In line with the view that they smooth household consumption, they are associated with a lower dispersion of growth outcomes. However, rental market regulations are also associated with a greater risk of severe downturns: this association is consistent with the view that rental regulations distort the housing market, creating a bias towards home ownership, which in turn can result in more mortgage borrowing.

Table 4. Regressions of ex-ante resilience measures on policy indicators

\begin{tabular}{lcc}
\hline & $\begin{array}{c}\text { GDP at risk (Q5) } \\
(1)\end{array}$ & $\begin{array}{c}\text { Severe-downturn } \\
\text { probability } \\
(2)\end{array}$ \\
\cline { 2 - 3 } LTV caps & -0.005 & $0.026^{* \star}$ \\
Risk weights & $(0.049)$ & $(0.013)$ \\
& -0.009 & 0.014 \\
Minimum Tier 1 capital & $(0.009)$ & $(0.018)$ \\
& 0.009 & $-0.305^{*}$ \\
Rental regulation & $(0.152)$ & $(0.144)$ \\
& $1.062^{\star *}$ & $2.687^{* \star}$ \\
- Tenure security & $(0.515)$ & $(1.378)$ \\
& $0.753^{* \star}$ & -0.075 \\
- Rent control & $(0.329)$ & $(0.846)$ \\
& 0.750 & $2.472^{* *}$ \\
\hline
\end{tabular}

Note: Standard errors are in parentheses; stars denote statistical significance: $* * * p<0.01, * * \mathrm{p}<0.05, * \mathrm{p}<0.1$. GDP-at-risk estimates come from quantile regressions using the specification laid out in Equation [1]. Crisis probability estimates come from probit regressions specified in Equation [2].

Source: Cournède, Sakha and Ziemann (2019[26]). 


\subsection{Policies and ex-post resilience}

\subsubsection{What are the links between housing-related policies and the severity of downturns?}

47. An array of ex-post resilience measures and indicators of the housing cycle have been related to macroprudential and housing policy indicators or proxies (see Annex E). ${ }^{8}$ The tightness of the link is assessed by running pooled regressions of resilience measures on policy indicators and looking at the significance of the coefficient on the policy indicator. This simple approach allows a look at the relationship despite the limitations of the data stemming from the small number of observed cycles and availability of policy indicators. ${ }^{9}$ The pooled regressions suggest that:

- Tighter LTV caps are associated with shorter booms and milder downturns. Tighter capital requirements are also linked with shallower cycles, but by contrast with LTV caps, they appear to be associated with stronger recoveries (Annex E).

- More stringent rental market regulations is associated with shorter and less pronounced booms but also shallower downturns, which would suggest that they might provide a certain degree of smoothing through the protection they offer. Higher levels of property taxation are also linked with a more limited amplitude of business cycles, also pointing to a smoothing role.

- Proxies for building restrictions suggest a link between tighter restrictions and more moderate housing price busts as well as faster recoveries of residential investment. This association is likely to reflect that building restrictions limit the scope for overbuilding, even if they may have other adverse implications.

\subsubsection{A look at causality from policy changes to real, financial and housing variables}

48. The links between policies and ex- post resilience indicators suffer from reverse causality. To deal with it, the impact of a policy change on real, financial and housing variables is reassessed using propensity-score matching techniques, which enable comparing the countries where policy changes occurred to similar countries that left policies unchanged. The idea is to compare two episodes that are as similar as possible, one with a policy change (treatment) and one without (control). The policy change can then be considered as exogenous, so that observed differences in outcomes between the treatment and control groups can be attributed to the policy change.

49. The analysis uses propensity matching. It first defines a treatment group, which consists of countries and years where and when policy changed. It then builds a probit model where one and three-year changes of real, financial and housing-related variables enter as predictors of policy changes. In a third step, the technique puts together a control

8. For greater robustness and a better understanding of the role of housing, the set of resilience indicators has been calculated not only for output gap cycles as in Table 3 but also real GDP, housing investment and house prices.

9. Cross-checking across different outcome variables gives a degree of comfort regarding robustness. Nevertheless, this approach calls for caution when interpreting the results, especially when it comes to the direction of causality. This is why an additional inquiry has been conducted using propensity score matching methods, which is contained in the next section. 
group of countries and years where observed developments were similar to the ones in the treatment group but where policy remained unchanged. Regressions are then used to obtain an estimated path measuring how the treatment group deviated from the control group as regards: i) credit to households, ii) real house prices, iii) housing investment and iv) private consumption.

50. The empirical analysis suggests that tightening LTV caps curbs credit to households and slows real house prices (Figure 15). Furthermore, there appears to be no sizeable impact on private consumption or aggregate output. These two sets of results point to stabilisation benefits of LTV caps with no significant macroeconomic costs.

Figure 15. Effect of tightening LTV caps
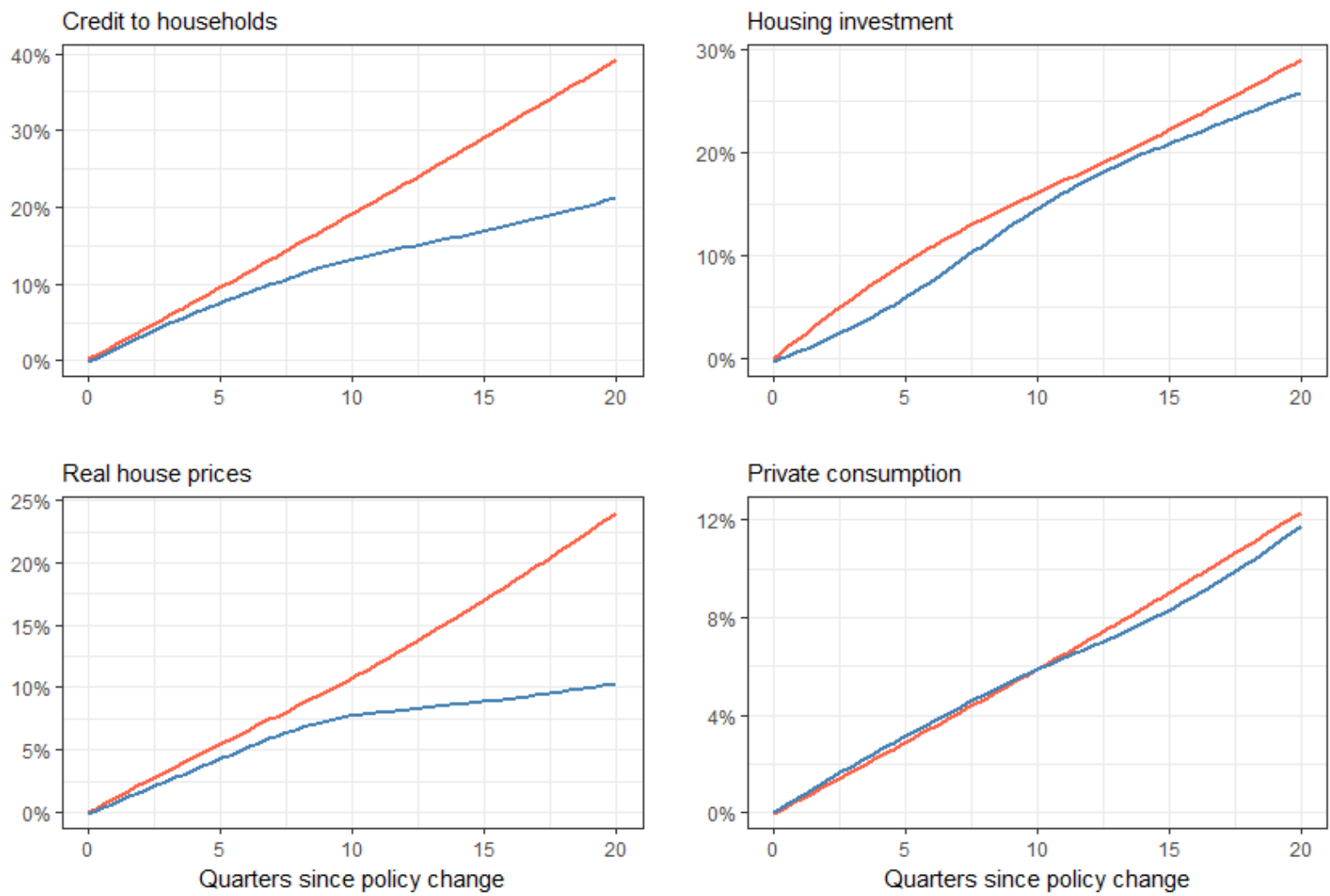

- No policy change - Tightening

Note: The treatment group consists of episodes where countries tightened their LTV caps at time $=0$. The control group comprises episodes where countries did not implement such a policy change although their conditions were otherwise similar. This treatment group has been determined by propensity matching techniques using a probit model with real and financial variables as covariates. The lines show averages for each group.

Source: Cournède, Sakha and Ziemann (2019[26]). 
51. Increasing risk weights imposed on banks for mortgage lending has similar limiting effects on credit and house prices as tightening LTV caps (Figure 16). ${ }^{10}$ By contrast with LTV caps, however, residential construction declines more strongly, so that tighter risk weights appear to slow down both GDP and consumption.

\section{Figure 16. Effect of tightening of risk weights}
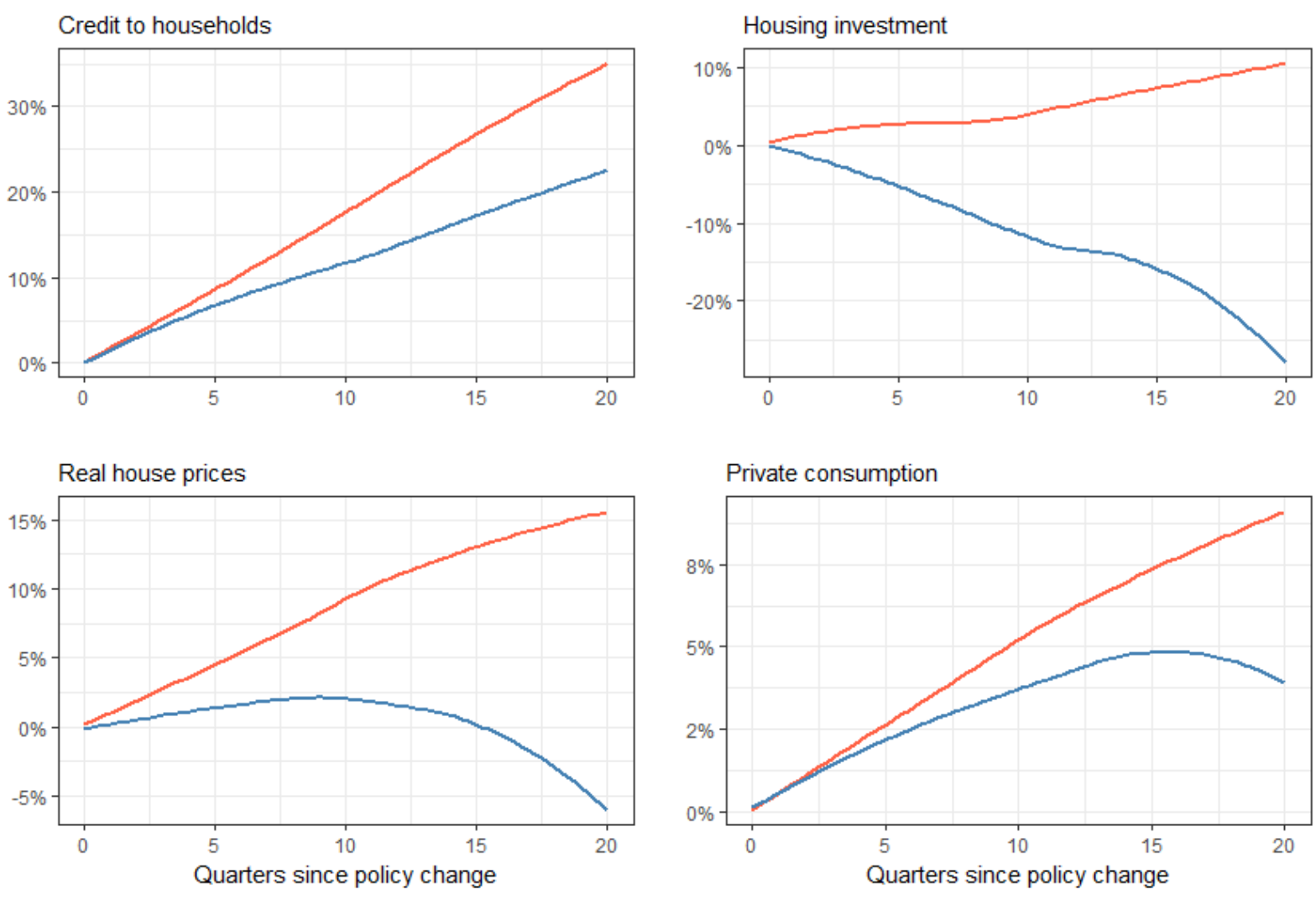

- No policy change - Tightening

Note: The treatment group consists of episodes where countries tightened their risk weights at time $=0$. The control group comprises episodes where countries did not implement such a policy change although their conditions were otherwise similar. This treatment group has been determined by propensity matching techniques using a probit model with real and financial variables as covariates. The lines show averages for each group.

Source: Cournède, Sakha and Ziemann (2019[26]).

52. Results for housing market regulation are less informative. They suggest that rental market deregulation alters investment opportunities leading to a shift towards real estate away from other forms of investment (Cournède, Sakha and Ziemann, 2019 $9_{[73]}$ ).

10. Capital requirements are not used in this part of the analysis to avoid excessively shrinking the sample. 


\subsection{Concluding remark}

53. The results, while constrained by limited hindsight on many policies, suggest a role for macroprudential and housing policies in containing the build-up of housing risks. They are in line with other empirical and model-based analyses suggesting that loan-to-value caps, mortgage risk weights and recurring property taxes can act as brakes on the accumulation of housing risk (IMF, 2019[31]). Debt-service-to-income ratios are also promising and could avoid the problem intrinsic to loan-to-value ratios that their denominator, house valuations, gets inflated during a housing bubble (Greenwald, $\left.2018_{[75]}\right)$. The lack of statistically identified effects probably reflects that they have been seldom used until recently. 


\section{References}

Acharya, V., R. Engle and D. Pierre (2014), "Testing macroprudential stress tests: The risk of regulatory risk weights”, Journal of Monetary Economics, Vol. 65, pp. 36-53.

Adalet McGowan, M. and D. Andrews (2015), "Labour Market Mismatch and Labour Productivity: Evidence from PIAAC Data", OECD Economics Department Working Papers, No. 1209, OECD Publishing, Paris, https://dx.doi.org/10.1787/5js1pzx1r2kb-en.

Aiyar, S., C. Calomiris and T. Wieladek (2014), "Does Macro-Prudential Regulation Leak? Evidence from a UK Policy Experiment", Journal of Money, Credit and Banking, Vol. 46/s1, pp. 181-214, http://dx.doi.org/10.1111/jmcb.12086.

Aizenman, J. and Y. Jinjarak (2009), "Current account patterns and national real estate markets", Journal of Urban Economics, Vol. 66/2, pp. 75-89, http://dx.doi.org/10.1016/j.jue.2009.05.002.

Akgun, O., B. Cournède and J. Fournier (2017), "Effects of the Tax Mix on Inequality and Growth", OECD Economics Department Working Papers, No. 1447, OECD Publishing.

Alam, Z. et al. (2019), "Digging Deeper - Evidence on the Effects of Macroprudential Policies from a New Database", IMF Working Paper, No. 19/66, IMF.

Alter, A., J. Dokko and D. Seneviratne (2018), "House Price Synchronicity, Banking Integration, and Global Financial Conditions", IMF Working Papers, No. 18/250, IMF, https://www.imf.org/en/Publications/WP/Issues/2018/11/28/House-Price-SynchronicityBanking-Integration-and-Global-Financial-Conditions-46380.

André, C. et al. (2018), "Can monetary policy lean against housing bubbles?", Department of Economics working paper series, No. 201877, University of Pretoria.

Andrews, D., A. Caldera Sánchez and Å. Johansson (2011), "Housing Markets and Structural Policies in OECD Countries", OECD Economics Department Working Papers, No. 836, OECD Publishing, Paris, https://dx.doi.org/10.1787/5kgk8t2k9vf3-en.

Baptista, R. et al. (2016), "Macroprudential policy in an agent-based model of the UK housing market", Bank of England, Working Paper No. 619.

Barceló, C. (2006), "Housing tenure and labour mobility: a comparison across European countries", Documentos de Trabajo, No. 0603, Banco de España, https://ideas.repec.org/p/bde/wpaper/0603.html.

Bednarek, P. et al. (2019), Capital Flows, Real Estate, and Local Cycles: Evidence from the German Cities, Firms and Banks, http://52.76.234.106/media/abfer-events-2019/annualconference/real-estate/AC19P6012_Capital_Flows_Real_Estate_and_City_Cycles.pdf. 
BIS (2018), "Moving forward with macroprudential frameworks", in BIS Annual Economic Report.

Boar, C. et al. (2017), What are the effects of macroprudential policies on macroeconomic performance? 1, BIS Quarterly Review, https://www.bis.org/publ/qtrpdf/r_qt1709g.pdf (accessed on 14 January 2019).

Borio, C. (2014), The international monetary and financial system: its Achilles heel and what to do about it, BIS, http://www.bis.org.

Bruneau, G., I. Christensen and C. Meh (2018), "Housing market dynamics and macroprudential policies", Canadian Journal of Economics, http://dx.doi.org/10.1111/caje.12346.

Bulow, J. and P. Klemperer (2012), "Regulated Prices, Rent Seeking, and Consumer Surplus", Journal of Political Economy, Vol. 120/1, pp. 160-186, http://dx.doi.org/10.1086/665416.

Caldera Sánchez, A. and O. Röhn (2016), "How do policies influence GDP tail risks?", OECD Working Paper, No. 1336, OECD Publishing, Paris, http://www.oecd.org/eco/workingpapers.

Caldera, A. and Å. Johansson (2013), "The price responsiveness of housing supply in OECD countries", Journal of Housing Economics, Vol. 22/3, pp. 231-249, http://dx.doi.org/10.1016/J.JHE.2013.05.002.

Canay, I. (2011), "A simple approach to quantile regression for panel data", The Econometrics Journal, Vol. 14/3, pp. 368-386, http://dx.doi.org/10.1111/j.1368-423X.2011.00349.x.

Cerutti, E., S. Claessens and L. Laeven (2017), "The use and effectiveness of macroprudential policies: New evidence", Journal of Financial Stability, Vol. 28, pp. 203-224, http://dx.doi.org/10.1016/J.JFS.2015.10.004.

Claessens, S., S. Ghosh and R. Mihet (2013), "Macro-prudential policies to mitigate financial system vulnerabilities", Journal of International Money and Finance, Vol. 39, pp. 153-185, http://dx.doi.org/10.1016/J.JIMONFIN.2013.06.023.

Cournède, B., S. Sakha and V. Ziemann (2019), "Housing Markets and Economic Resilience”, in OECD Working Paper Series, OECD Publishing (forthcoming).

Davidoff, I. and A. Leigh (2013), "How Do Stamp Duties Affect the Housing Market?", http://dx.doi.org/10.1111/1475-4932.12056.

Davis, S. and J. Haltiwanger (2019), "Dynamism Diminished: The Role of Housing Markets and Credit Conditions", National Bureau of Economic Research Working Paper Series, Vol. No. 25466, http://dx.doi.org/10.3386/w25466.

De Crescenzio, A. and E. Lepers (2019), "Measures of real estate purchases by non-residents impact and spillovers", OECD Working Papers (forthcoming), OECD.

Diamond, R., T. Mcquade and F. Qian (2018), "The Effects of Rent Control Expansion on Tenants, Landlords, and Inequality: Evidence from San Francisco", Journal of Political Economy, forthcoming, https://web.stanford.edu/ diamondr/DMQ.pdf. 
ECB (2017), "The growing role of non-bank lending to households - a case study on the Netherlands", in Financial Stability Review, ECB.

Estrella, A., A. Rodrigues and S. Schich (2003), "How stable is the predictive power of the yield curve? Evidence from Germany and the United States", The Review of Economics and Statistics, Vol. 85/3, pp. 629-644, https://www.mitpressjournals.org/doi/pdf/10.1162/003465303322369777.

Ferrero, A., R. Harrison and B. Nelson (2018), "Concerted efforts? Monetary policy and macroprudential tools", Staff Working Paper, No. 727, Bank of England, http://www.bankofengland.co.uk/working-paper/Working-papers.

Funke, M. and M. Paetz (2016), "Dynamic Stochastic General Equilbirum-Based Assessment of Nonlinear Macroprudential Policies: Evidence from Hong Kong", Pacific Economic Review, Vol. 23/4, pp. 632-657, http://dx.doi.org/10.1111/1468-0106.12170.

Gabarro, M. et al. (2019), "Macroprudential Policy and Household Leverage: Evidence from Administrative Household-Level Data", CEPR Discussion Paper, No. 13503.

Garda, P. (2016), "The Ins and Outs of Employment in 25 OECD Countries", OECD Economics Department Working Papers, No. 1350, OECD Publishing, Paris, https://dx.doi.org/10.1787/3f9fa009-en.

Gellatly, G. and R. Morrissette (2017), "Non-resident Ownership of Residential Properties in Toronto and Vancouver: Initial Information from the Canadian Housing Statistics Program", Economic Insights, Statistics Canada, https://www150.statcan.gc.ca/n1/pub/11-626-x/11-626x2017078-eng.htm.

Glaeser, E. and J. Gyourko (2018), “The Economic Implications of Housing Supply”, Journal of Economic Perspectives, http://dx.doi.org/10.1257/jep.32.1.3.

Glaeser, E. and E. Luttmer (2003), "The Misallocation of Housing Under Rent Control", American Economic Review, Vol. 93/4, pp. 1027-1046, http://dx.doi.org/10.1257/000282803769206188.

Goodman, L. and C. Mayer (2018), "Homeownership and the American Dream", Journal of Economic Perspectives, http://dx.doi.org/10.1257/jep.32.1.31.

Greenwald, D. (2018), “The Mortgage Channel of Macroeconomic Transmission”, mimeo.

Griffin, J., S. Kruger and G. Maturana (2018), "What Drove the 2003-2006 House Price Boom and Subsequent Collapse? Disentangling Competing Explanations", mimeo.

Gyourko, J. and P. Linneman (1989), "Equity and efficiency aspects of rent control: An empirical study of New York City", Journal of Urban Economics, Vol. 26/1, pp. 54-74, http://dx.doi.org/10.1016/0094-1190(89)90027-2.

Harding, D. and A. Pagan (2002), "Dissecting the cycle: a methodological investigation", Journal of Monetary Economics, Vol. 49/2, pp. 365-381, http://dx.doi.org/10.1016/S03043932(01)00108-8. 
Hermansen, M. and O. Röhn (2017), "Economic resilience: The usefulness of early warning indicators in OECD countries", OECD Journal: Economic Studies, Vol. 2016/1, https://www.oecd-ilibrary.org/docserver/eco studies-20165jg2ppjrd6r3.pdf?expires $=1547983022 \&$ id $=\overline{\mathrm{i}}$ \&accname $=$ ocid $84004878 \&$ checksum $=3$ A3C6 140FEC597236FBC3673C21D5C42.

Hilber, C. and T. Lyytikäinen (2017), "Transfer taxes and household mobility: Distortion on the housing or labor market?", Journal of Urban Economics, http://dx.doi.org/10.1016/j.jue.2017.06.002.

Hsieh, C. and E. Moretti (2015), "Housing Constraints and Spatial Misallocation", NBER Working Papers 21154, http://www.nber.org/papers/w21154.

IMF (2019), "Downside Risks to House Prices", in Global Financial Stability Report, IMF, https://www.imf.org/en/Publications/GFSR/Issues/2019/03/27/Global-Financial-StabilityReport-April-2019\#ch2.

IMF (2018), “A Bumpy Road Ahead”, in Global Financial Stability Report, IMF, https://www.imf.org/en/Publications/GFSR/Issues/2018/04/02/Global-Financial-StabilityReport-April-2018.

Kearns, J. (2017), Australian Property - Financial Stability and Foreign Involvement, Speech, https://www.rba.gov.au/speeches/2017/sp-so-2017-11-20.html (accessed on 10 April 2019).

Kelly, R., F. McCann and C. O'Toole (2018), "Credit conditions, macroprudential policy and house prices", Journal of Housing Economics, http://dx.doi.org/10.1016/j.jhe.2018.05.005.

Kholodilin, K. (2018), "Measuring Stick-Style Housing Policies: A Multi-Country Longitudinal Database of Governmental Regulations", DIW Discussion Papers, No. 1727, Deutsches Institut für Wirtschaftsforschung (DIW), Berlin, http://dx.doi.org/10.2139/ssrn.3146755.

Kholodilin, K., A. Mense and C. Michelsen (2016), "Market Break or Simply Fake? Empirics on the Causal Eff ects of Rent Controls in Germany", DIW Discussion Papers, No. 1584, Deutsches Institut für Wirtschaftsforschung (DIW), Berlin, http://www.diw.de/discussionpapers.

Kim, S. and A. Mehrotra (2018), "Effects of Monetary and Macroprudential Policies - Evidence from Four Inflation Targeting Economies", Journal of Money, Credit and Banking, Vol. 50/5, pp. 967-992, http://dx.doi.org/10.1111/jmcb.12495.

Kim, S. and D. Yang (2009), "The Impact of Capital Inflows on Asset Prices in Emerging Asian Economies: Is Too Much Money Chasing Too Little Good?", Open Economies Review, Vol. 22/2, pp. 293-315, http://dx.doi.org/10.1007/s11079-009-9124-x.

Kuncl, M. (2016), "Assessment of the Effects of Macroprudential Tightening in Canada", Staff Analytical Note, No. 2016-12, Bank of Canada, http://www.bank-banquecanada.caStaffAnalyticalNote/Noteanalytiquedupersonnel2016-12.

Laliotis, D. and J. Población (2016), "Agent Based Models for the Assessment of the Application LTV/LTI Cap Macroprudential Measures”, European Central Bank. 
Lane, T. (2016), Monetary Policy and Financial Stability_Looking for the Right Tools, https://www.bankofcanada.ca/2016/02/monetary-policy-financial-stability-looking-righttools/.

Laufer, S. et al. (2018), “The Effect of LTV-Based Risk Weights on House Prices: Evidence from an Israeli Macroprudential Policy”, SSRN Electronic Journal. 10.2139/ssrn. 3297797.

Lim, C. et al. (2011), "Macroprudential Policy: What Instruments and How to use them?", IMF Working Paper, No. WP/11/238, IMF.

Lim, T. (2018), "Housing as collateral, financial constraints, and small businesses", Review of Economic Dynamics, Vol. 30, pp. 68-85, http://dx.doi.org/10.1016/j.red.2018.03.001.

Lux, M. and P. Sunega (2012), "Labour Mobility and Housing”, Urban Studies, Vol. 49/3, pp. 489-504, http://dx.doi.org/10.1177/0042098011405693.

Metcalf, G. (2018), "Sand Castles Before the Tide? Affordable Housing in Expensive Cities", Journal of Economic Perspectives, Vol. 32/1, pp. 59-80, http://dx.doi.org/10.1257/jep.32.1.59.

Muellbauer, J. and A. Murphy (1997), "Booms and Busts in the UK Housing Market", The Economic Journal, Vol. 107/445, pp. 1701-1727, http://dx.doi.org/10.1111/j.14680297.1997.tb00076.x.

National Commission on the Causes of the Financial and Economic Crisis (2010), Final Report of the National Commission on the Causes of the Financial and Economic Crisis in the United States, US Government, Washington DC, https://cybercemetery.unt.edu/archive/fcic/20110310173545/http://www.gpo.gov/fdsys/pkg/G PO-FCIC/pdf/GPO-FCIC.pdf (accessed on 10 April 2019).

OECD (2019), OECD Economic Outlook, Volume 2019 Issue 1: Preliminary version, OECD Publishing, Paris, https://dx.doi.org/10.1787/b2e897b0-en.

OECD (2019), OECD Economic Surveys: Sweden 2019, OECD Publishing, Paris, https://dx.doi.org/10.1787/c510039b-en.

OECD (2018), OECD Economic Surveys: Canada 2018, OECD Publishing, Paris, https://dx.doi.org/10.1787/eco surveys-can-2018-en.

OECD (2018), OECD Economic Surveys: Netherlands 2018, OECD Publishing, Paris, https://dx.doi.org/10.1787/eco surveys-nld-2018-en.

OECD (2018), Rethinking Urban Sprawl: Moving Towards Sustainable Cities, OECD Publishing, Paris, https://dx.doi.org/10.1787/9789264189881-en.

OECD (2018), Taxation of Household Savings, OECD Tax Policy Studies, No. 25, OECD Publishing, Paris, https://dx.doi.org/10.1787/9789264289536-en.

OECD (2017), OECD Economic Surveys: Belgium 2017, OECD Publishing, Paris, https://dx.doi.org/10.1787/eco surveys-bel-2017-en. 
OECD (2017), OECD Economic Surveys: Switzerland 2017, OECD Publishing, Paris, https://dx.doi.org/10.1787/eco_surveys-che-2017-en.

OECD (2011), "Housing and the Economy: Policies for Renovation", in Economic Policy Reforms 2011: Going for Growth, OECD Publishing, Paris, https://dx.doi.org/10.1787/growth-2011-46-en.

Richter, B., M. Schularick and I. Shim (2018), "The Costs of Macroprudential Policy”, Journal of International Economics, forthcoming, https://www.nber.org/papers/w24989.pdf.

Sá, F., P. Towbin and T. Wieladek (2014), "Capital Inflows, Financial Structure And Housing Booms", Journal of the European Economic Association, Vol. 12/2, pp. 522-546, http://dx.doi.org/10.1111/jeea.12047.

Sá, F. and T. Wieladek (2015), "Capital Inflows and the U.S. Housing Boom”, Journal of Money, Credit and Banking, Vol. 47/S1, pp. 221-256, http://dx.doi.org/10.1111/jmcb.12200.

Salvi del Pero, A. et al. (2016), "Policies to promote access to good-quality affordable housing in OECD countries", OECD Social, Employment and Migration Working Papers, No. 176, OECD Publishing, Paris, https://dx.doi.org/10.1787/5jm3p5gl4djd-en.

Statistics New Zealand (2018), Just over 3 percent of home transfers go to overseas buyers Stats NZ, https://www.stats.govt.nz/news/just-over-3-percent-of-home-transfers-go-tooverseas-buyers (accessed on 10 April 2019).

Tillmann, P. (2013), "Capital inflows and asset prices: Evidence from emerging Asia", Journal of Banking \& Finance, Vol. 37/3, pp. 717-729, http://dx.doi.org/10.1016/j.jbankfin.2012.10.017.

Turner, D., T. Chalaux and H. Morgavi (2018), "Fan charts around GDP projections based on probit models of downturn risk", OECD Economics Department Working Papers, No. 1521, OECD Publishing, Paris, https://dx.doi.org/10.1787/d7c20354-en.

Xiong, Q. and A. Mavropoulos (2018), "Housing Consumption and Macroprudential Policies in Europe: An Ex Ante Evaluation", Discussion Papers, No. 17/2018, http://www.iwh-halle.de. 


\section{Annex A. Synchronisation of housing and business cycles by country}

Cumulative 3-year growth rates are shown

BEL
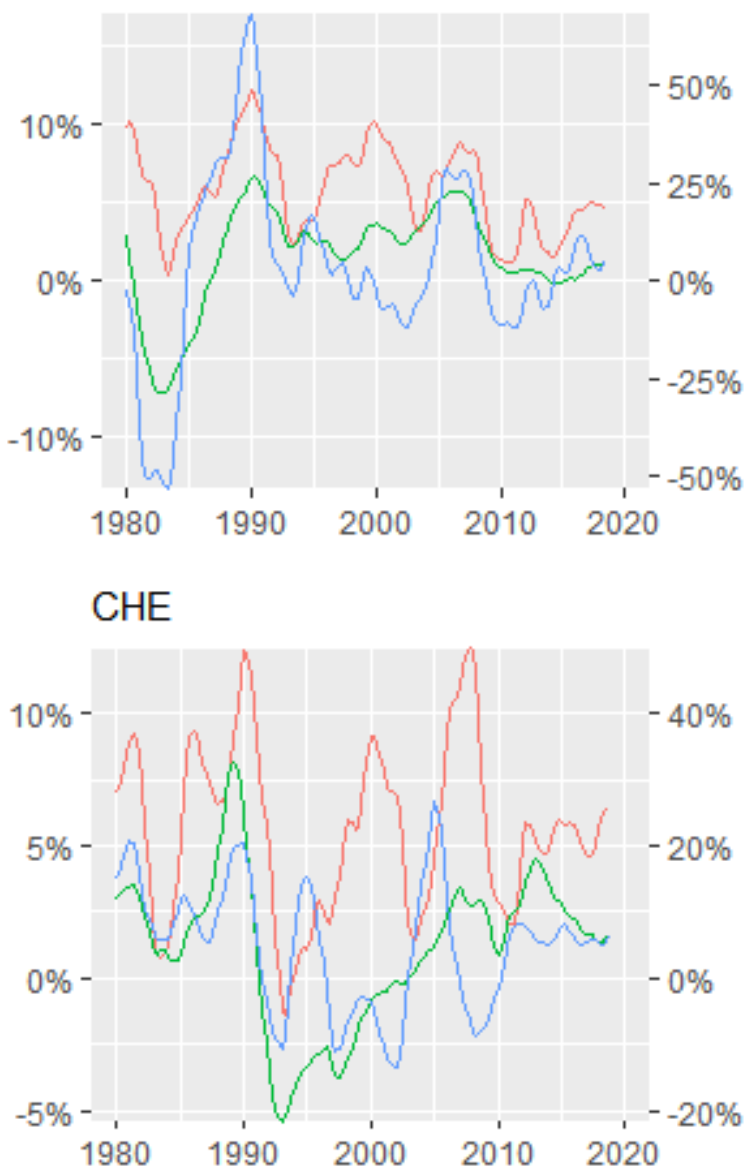

FRA

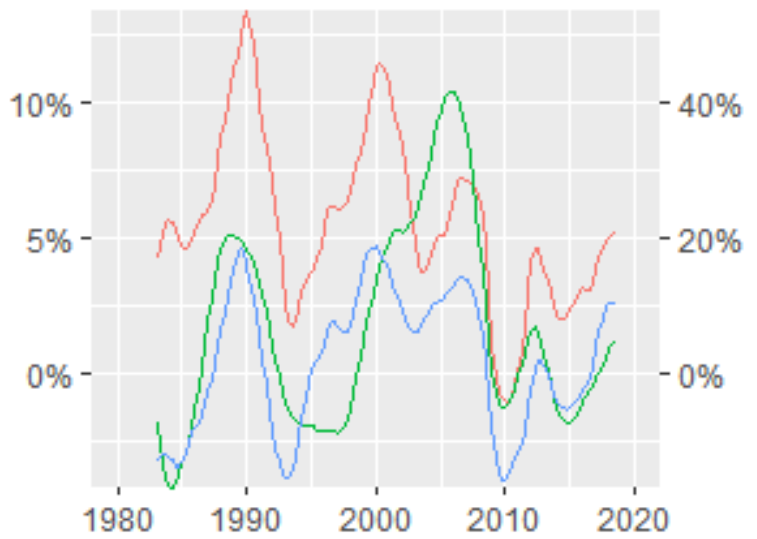

- GDP - House prices (RHS)
CAN
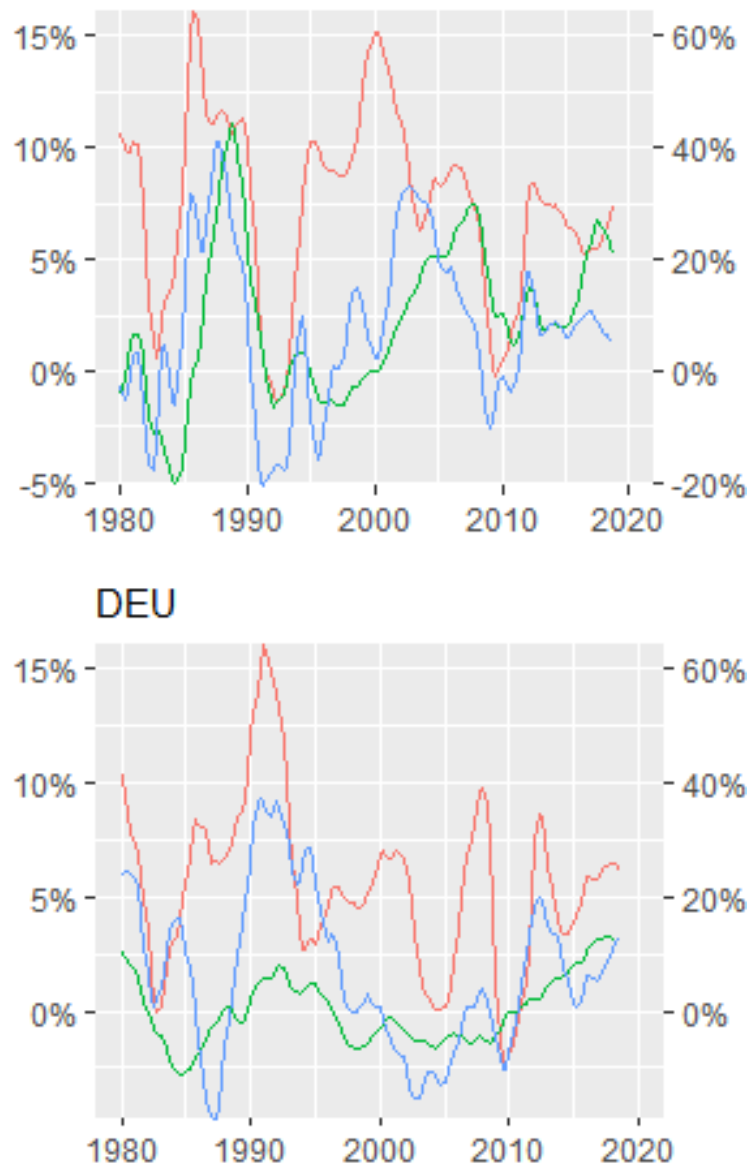

GBR

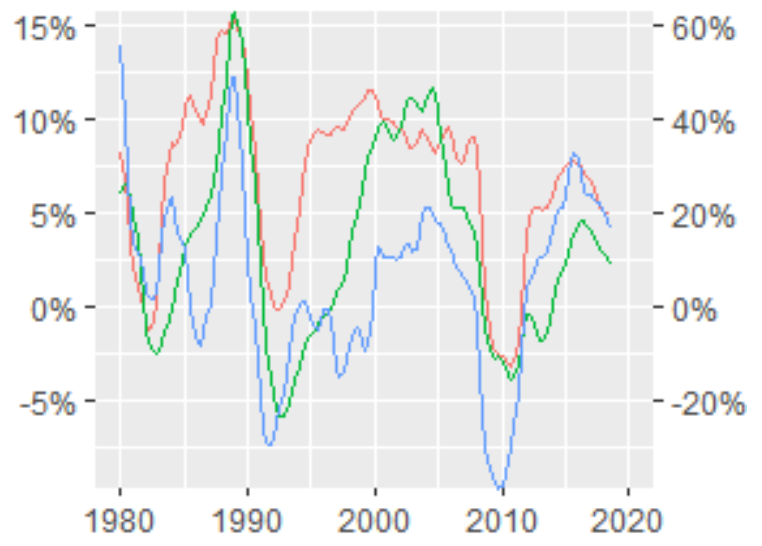

\section{- Residential investment (RHS)}


Cumulative 3-year growth rates are shown
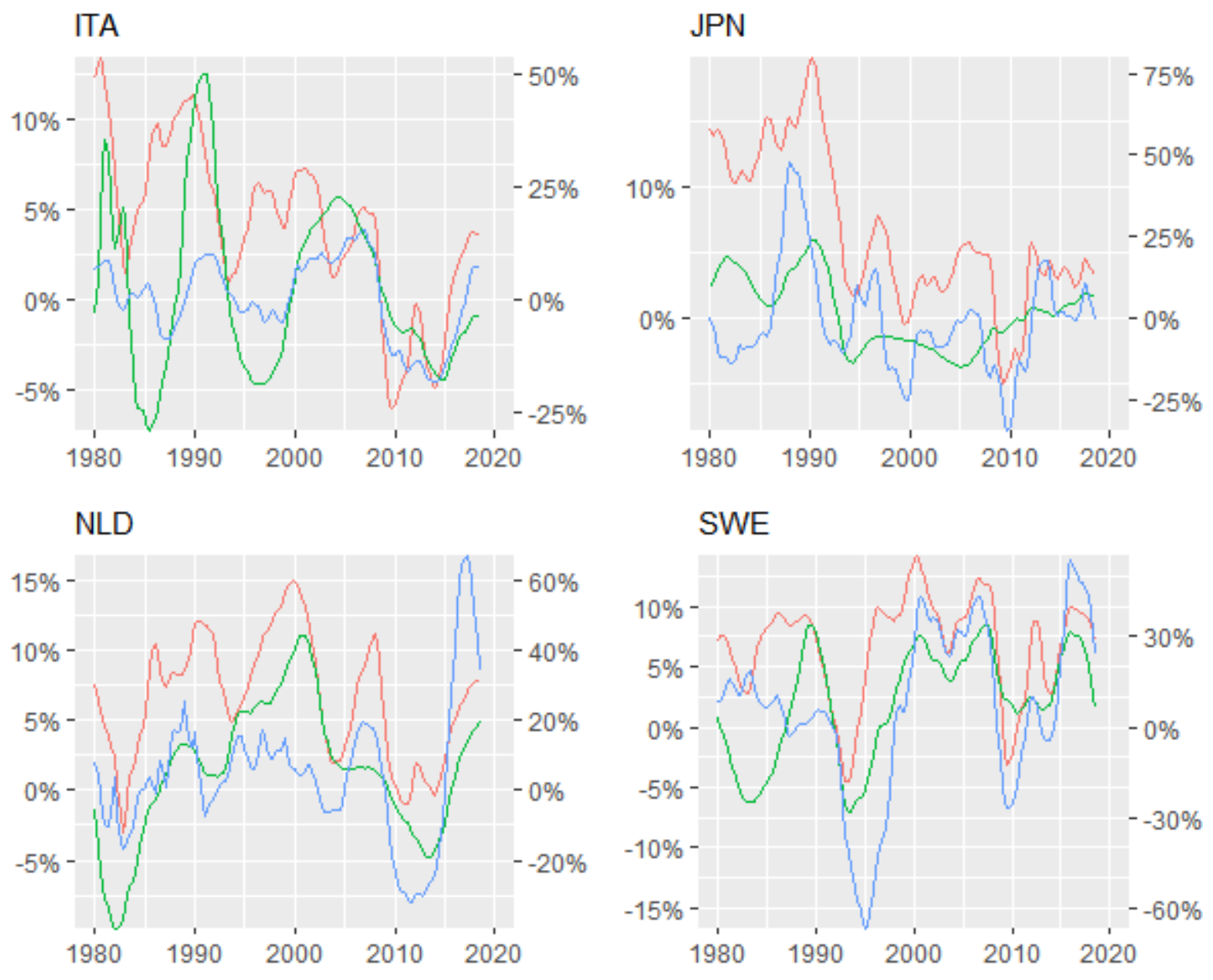

\section{USA}

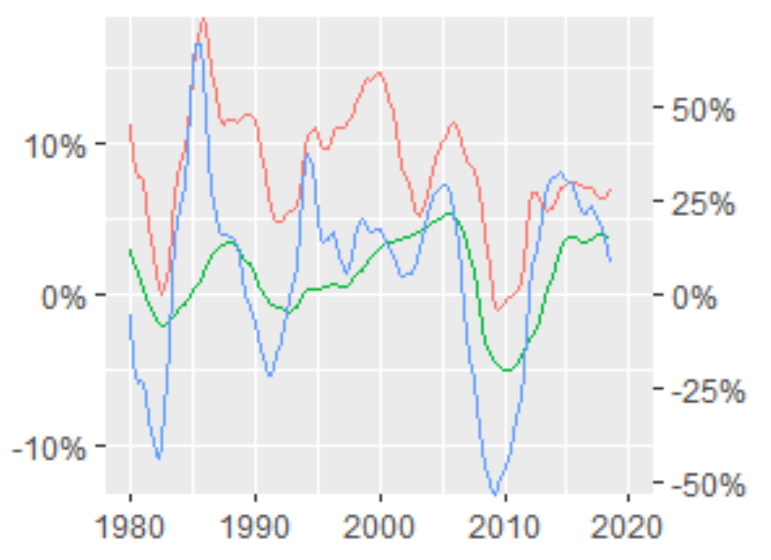

— GDP - House prices (RHS) — Residential investment (RHS) 
Indices are shown $(2000 Q 1=100)$
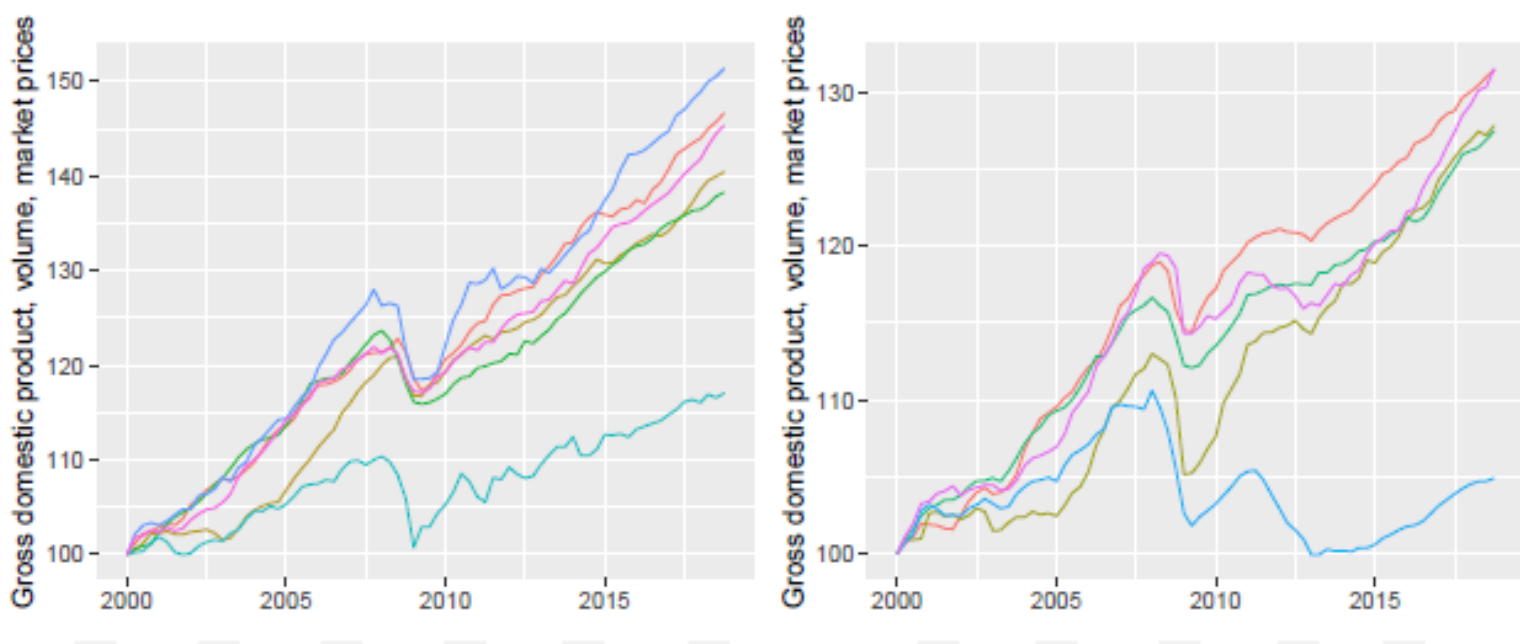

- CAN - CHE - GBR - JPN — SWE - USA

- BEL - DEU — FRA - ITA - NLD
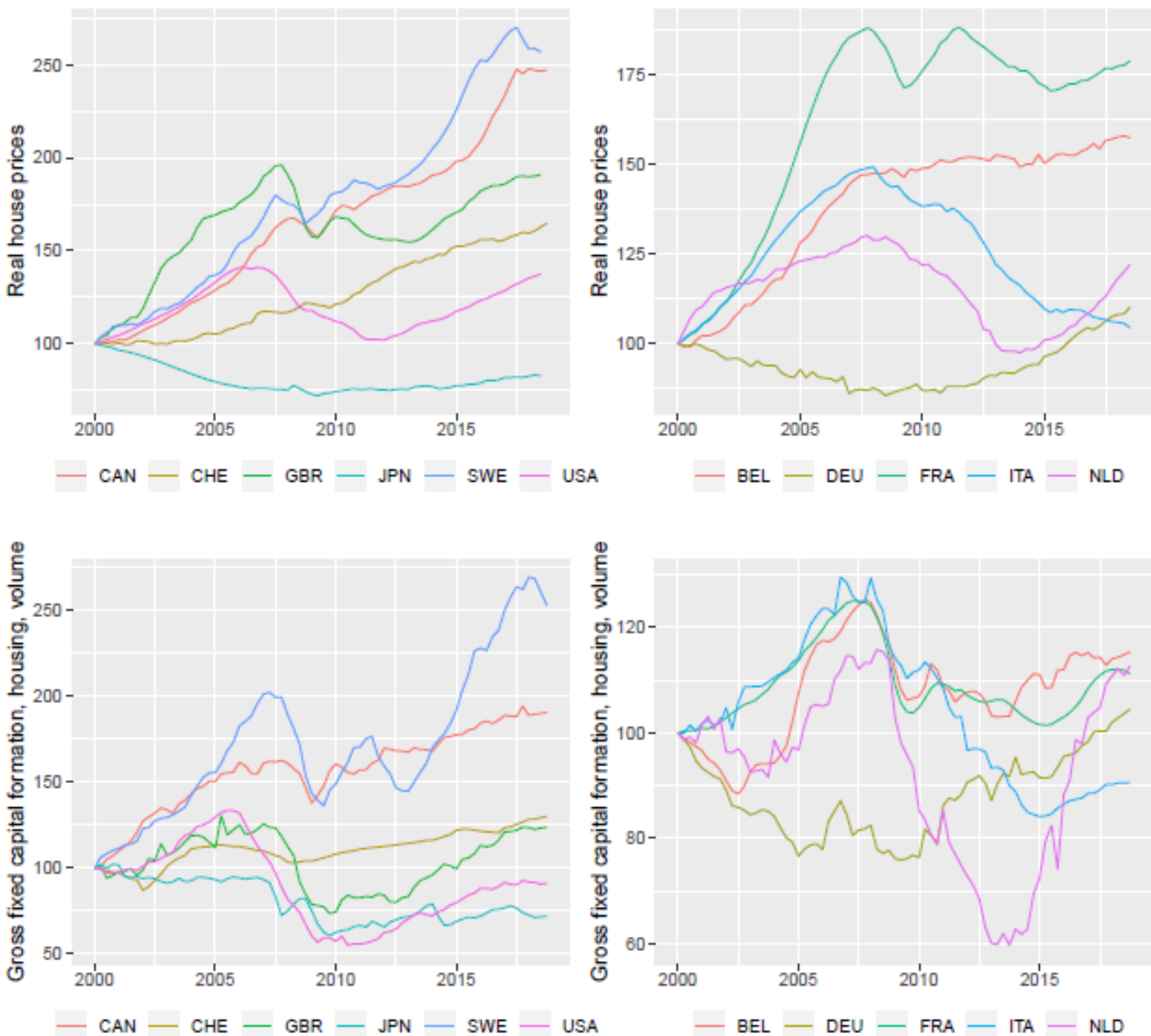

- CAN — CHE — GBR - JPN — SWE — USA

- BEL - DEU — FRA - ITA - NLD 


\section{Annex B. Sources of the policy variables}

\begin{tabular}{|c|c|c|}
\hline Variable & Description & Source \\
\hline LTV caps & Maximum loan-to-value ratios applied to mortgage loans. & $\begin{array}{l}\text { ECB's Macroprudential Policies } \\
\text { Evaluation Database (MaPPED) } \\
\text { complemented by own research }\end{array}$ \\
\hline Capital requirements & $\begin{array}{l}\text { Minimum regulatory Tier } 1 \text { ratio multiplied with unweighted average of risk } \\
\text { weights for mortgage loans with an LTV ranging from } 50 \text { to } 130 \text {. }\end{array}$ & $\begin{array}{l}\text { ECB's Macroprudential Policies } \\
\text { Evaluation Database (MaPPED) } \\
\text { complemented by own research }\end{array}$ \\
\hline Rent control & $\begin{array}{l}\text { Index reflecting on the number of regulations that restrict rent increases } \\
\text { including real rent freezes, nominal rent freezes, rent level control, limits of } \\
\text { decontrolling (e.g. change of tenant, new or vacant dwelling) as well as } \\
\text { restrictions on subletting }\end{array}$ & DIW (Kholodilin, 2018[76]) \\
\hline Tenure security & $\begin{array}{l}\text { Index capturing the intensity of regulation protecting tenants from eviction } \\
\text { including the prohibition of short-term tenancies. }\end{array}$ & DIW (Kholodilin, 2018[76]) \\
\hline Social rental market & $\begin{array}{l}\text { Number of social rental dwellings as a share of the total number of } \\
\text { dwellings, } 2015 \text { or latest year available. }\end{array}$ & OECD Affordable Housing Database \\
\hline Housing allowances & Public spending on housing allowances as \% of GDP, 2015. & OECD Affordable Housing Database \\
\hline $\begin{array}{l}\text { Property tax rate } \\
\text { (owner-occupied) }\end{array}$ & $\begin{array}{l}\text { Marginal effective tax rates (METR) on owner-occupied are derived as the } \\
\text { differences between the pre- and post-tax rates of return of a marginal } \\
\text { investment divided by the pre-tax rate of return of that investment where } \\
\text { post-tax real rate is the minimum rate of return necessary to make the } \\
\text { investment worthwhile. }\end{array}$ & $\begin{array}{l}\text { OECD Tax Policy Studies paper (OECD, } \\
\text { 2018[67]) }\end{array}$ \\
\hline $\begin{array}{l}\text { Property tax rate } \\
\text { (rental) }\end{array}$ & $\begin{array}{l}\text { Marginal effective tax rates (METR) on rental dwellings are derived as the } \\
\text { differences between the pre- and post-tax rates of return of a marginal } \\
\text { investment divided by the pre-tax rate of return of that investment where } \\
\text { post-tax real rate is the minimum rate of return necessary to make the } \\
\text { investment worthwhile. }\end{array}$ & $\begin{array}{l}\text { OECD Tax Policy Studies paper (OECD, } \\
2018[67])\end{array}$ \\
\hline $\begin{array}{l}\text { Urban sprawl } \\
\text { (restrictiveness) }\end{array}$ & $\begin{array}{l}\text { Composite indicator derived from the first principal component of changes } \\
\text { in } 8 \text { urban sprawl indicators from } 2000 \text { to } 2014 \text {. The indicator is associated } \\
\text { with an increasing share of low populated areas and decentralisation. } \\
\text { "Urban sprawl restrictiveness" is defined as the negative of the urban sprawl } \\
\text { composite indicator. }\end{array}$ & $\begin{array}{l}\text { Own calculations based on OECD's } \\
\text { Urban Sprawl indicators (OECD, } \\
2018_{[77])}\end{array}$ \\
\hline $\begin{array}{l}\text { Densification } \\
\text { (restrictiveness) }\end{array}$ & $\begin{array}{l}\text { Composite indicator derived from the second principal component of } \\
\text { changes in } 8 \text { urban sprawl indicators from } 2000 \text { to } 2014 \text {. "Densification } \\
\text { restrictiveness" is defined as the negative of the densification composite } \\
\text { indicator. }\end{array}$ & $\begin{array}{l}\text { Own calculations based on OECD's } \\
\text { Urban Sprawl indicators (OECD, } \\
2018_{[77])}\end{array}$ \\
\hline $\begin{array}{l}\text { Zoning } \\
\text { (restrictiveness) }\end{array}$ & $\begin{array}{l}\text { Composite indicator derived from the third principal component of changes } \\
\text { in } 8 \text { urban sprawl indicators from } 2000 \text { to } 2014 \text {. The indicator is associated } \\
\text { with urban expansion and declines in fragmentation. "Zoning } \\
\text { restrictiveness" is defined as the negative of the zoning composite indicator. }\end{array}$ & $\begin{array}{l}\text { Own calculations based on OECD's } \\
\text { Urban Sprawl indicators (OECD, } \\
2018_{[77])}\end{array}$ \\
\hline
\end{tabular}




\section{Annex C. Land use policies}

54. Land use restrictions, which limit the freedom to build dwellings on new land or to densify existing built areas, have implications for housing cycles and economic resilience. Tight policies, which make building less responsive to demand, imply larger price swings but smaller construction swings (Glaeser and Gyourko, 2018[78]). Both price and construction booms can contribute to the business and financial cycle and to the risk of damaging crises. The effect of land-use restrictions on economic resilience therefore remains an open question. By contrast, the strong effect of tight land-use restrictions in terms of increasing housing costs is well established (Glaeser and Gyourko, 2018 [78]): for instance, a recent study estimated that building constraints cumulatively reduced US GDP by $9 \%$ over 1964-2009 by comparison with a scenario of flexible land use policies (Hsieh and Moretti, 2015 $[79])$. A study that criticised this estimate for being too large still concluded that land use regulation reduces US national output by at least 2\% (Glaeser and Gyourko, $\left.2018_{[78]}\right)$. Land use regulations are complex and quantitative indicators not readily available. Recent OECD work has produced several indicators for urban sprawl for most OECD countries $\left(\mathrm{OECD}, 2018_{[77]}\right)$. These indicators can be used to derive composite indicators for urban sprawl (Box 3). 


\section{Box 3. Gauging land use policies from urban sprawl data}

In the absence of harmonised quantitative indicators for land use regulation, outcome variables of urban sprawl could serve as a proxy for impediments to housing supply. Recent work at the OECD has produced a range of useful metrics in this regard $\left(\right.$ OECD, $\left.2018_{[77]}\right)$. To summarise the information contained in 8 urban sprawl indicators, more precisely their change between 2000 and 2014, principal component analysis can be used (Table C.1.). The resulting first principal component reflects urban sprawl in the narrow sense and is associated with an increasing share of people living in low-density areas. The second principal component reflects densification of areas outside the urban core leading to polycentric structures with more but smaller urban centres. The third principal component reflects the extension of urban footprint and is associated with an increase of developed land and a reduction of fragmentation.

Table C.1. Urban sprawl indicators: Principal component analysis

\begin{tabular}{|c|c|c|c|c|}
\hline Variable & Description & PC1 & PC2 & PC3 \\
\hline Population density & Average functional urban area population density: number of inhabitants $/ \mathrm{km}^{2}$ & -0.90 & & \\
\hline Fragmentation & Fragmentation index: number of urban fabric fragments per km² & & & -0.55 \\
\hline Polycentricity & Number of urban centres & & 0.75 & \\
\hline Coefficient of variation & Coefficient of variation of population density & & 0.60 & \\
\hline Decentralisation & Share of functional urban area population living outside of urban centres & & -0.69 & \\
\hline Land to density allocation & $\begin{array}{l}\text { Percentage of urban footprint occupying areas of density below } 2500 \\
\text { inhabitants } / \mathrm{km}^{2}\end{array}$ & 0.90 & & \\
\hline Population to density allocation & $\begin{array}{l}\text { Percentage of population living in areas with a density below } 2500 \\
\text { inhabitants } / \mathrm{km}^{2}\end{array}$ & 0.92 & & \\
\hline Artificial area & Sum of functional urban area's artificial area in $\mathrm{km}^{2}$ & & & 0.89 \\
\hline
\end{tabular}

Note: Principal component analysis on the change between 2000 and 2014 of eight urban sprawl indicators is performed. The table shows loadings with a contribution of more than $15 \%$ per principal component (PC) for the first three PCs that explain more than $75 \%$ of the overall variation in the data.

Source: Rethinking Urban Sprawl, Moving towards Sustainable Cities (OECD, 2018[77]).

Non-policy drivers of urban sprawl include population growth, the rise in household income, the decline of commuting costs and individual preferences for living in low-density areas. Assuming common trends for individual preferences and commuting costs across countries, controlling for increases in household income allows to derive unexplained changes to urban sprawl, densification and the extension of the urban footprint. The inverse of these indicators are then used as proxies for the respective restrictiveness across countries (Figure C.1).

Figure C.1. Land use restrictiveness indicators
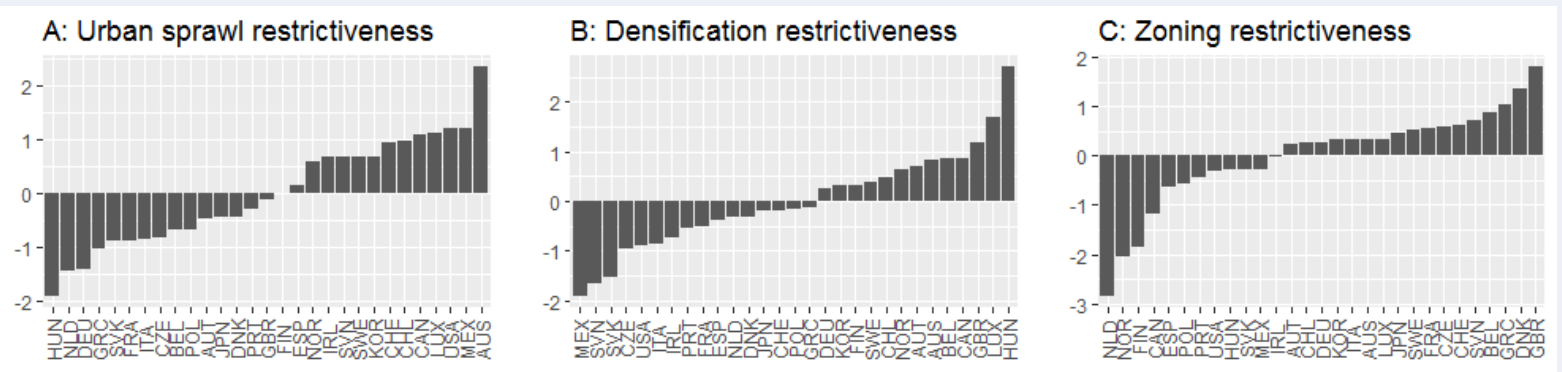

Note: Based on composite indicators for urban sprawl, densification and newly developed urban land drawn from principal component analysis of changes to urban sprawl indicators between 2000 and 2014 (Table C.1.). Restrictiveness indicators are obtained as the inverse of the principal components after controlling for the increase in household disposable income.

Source: Own calculations, based on (OECD, 2018[77]) 
Annex D. Averages of policy variables over 2007-12

\begin{tabular}{|c|c|c|c|c|c|c|c|c|c|c|c|}
\hline & \multicolumn{2}{|c|}{ Macroprudential } & \multicolumn{2}{|c|}{ Rental rec } & \multicolumn{2}{|c|}{ Public support } & \multicolumn{2}{|c|}{ Property taxation } & \multicolumn{3}{|c|}{ Land use restrictiveness } \\
\hline & LTV & Capital & Rent & Tenure & Social & Housing & Property tax & Property & Urban & Densification & Zoning \\
\hline ARG & & & 0.27 & 0.75 & & & 0.28 & 0.57 & & & \\
\hline AUS & & 8.00 & 0.17 & 0.00 & 4.90 & 0.27 & 0.15 & 0.88 & 2.33 & 0.85 & 0.34 \\
\hline AUT & & 8.00 & 0.17 & 0.75 & 26.20 & 0.16 & 0.15 & 0.59 & -0.48 & 0.70 & 0.23 \\
\hline BEL & & 8.00 & 0.17 & 0.25 & & & 0.49 & 0.51 & -0.69 & 0.86 & 0.89 \\
\hline BRA & & & 0.00 & 0.50 & & & & & & & \\
\hline CAN & 94.87 & 8.00 & 0.33 & 0.25 & 4.10 & & 0.39 & 0.75 & 1.08 & 0.86 & -1.17 \\
\hline CHE & 93.33 & 8.00 & 0.33 & 0.50 & & & 0.23 & 0.28 & 0.94 & -0.17 & 0.62 \\
\hline $\mathrm{CHL}$ & & & 0.17 & 0.25 & & 0.01 & 0.21 & 0.21 & 0.96 & 0.47 & 0.27 \\
\hline $\mathrm{CHN}$ & 75.26 & 8.00 & & & & & & & & & \\
\hline $\mathrm{COL}$ & & & 0.50 & 0.25 & & & 0.17 & 0.17 & & & \\
\hline CRI & & & & & & & & & & & \\
\hline CZE & 97.13 & 8.00 & 0.02 & 0.50 & 0.50 & 0.27 & 0.11 & 0.22 & -0.82 & -0.96 & 0.59 \\
\hline DEU & & 8.00 & 0.40 & 0.50 & 3.90 & 0.59 & 0.19 & 0.66 & -1.40 & 0.26 & 0.27 \\
\hline DNK & 82.37 & 8.00 & 0.77 & 0.40 & 22.20 & 0.48 & 0.21 & 0.49 & -0.44 & -0.30 & 1.36 \\
\hline ESP & & 8.84 & 0.33 & 1.00 & & 0.01 & 0.37 & 0.48 & 0.16 & -0.37 & -0.64 \\
\hline EST & & 8.84 & 0.50 & 0.50 & 1.40 & 0.04 & 0.00 & 0.22 & & & \\
\hline FIN & 99.74 & 8.00 & 0.17 & 0.25 & 12.80 & 0.82 & 0.12 & 0.50 & 0.01 & 0.32 & -1.85 \\
\hline FRA & & 8.00 & 0.32 & 1.00 & 18.70 & 0.83 & 0.23 & 0.47 & -0.88 & -0.50 & 0.57 \\
\hline GBR & & 8.00 & 0.17 & 0.25 & 17.60 & 1.41 & 0.28 & 0.55 & -0.11 & 1.17 & 1.80 \\
\hline GRC & & 8.00 & 0.00 & 0.00 & & & 0.27 & 0.26 & -1.02 & -0.12 & 1.04 \\
\hline HUN & 80.00 & 8.00 & & & 4.00 & & 0.15 & 0.30 & -1.89 & 2.70 & -0.29 \\
\hline IDN & 83.96 & 8.00 & & & & & & & & & \\
\hline IND & 83.75 & 9.00 & & & & & & & & & \\
\hline $\mathrm{IRL}$ & & 8.00 & 0.33 & 0.25 & 8.70 & 0.21 & 0.07 & 0.58 & 0.66 & -0.74 & -0.03 \\
\hline ISL & & & 0.00 & 0.25 & & & 0.16 & 0.36 & & & \\
\hline ISR & & & & & & & 0.10 & 0.28 & & & \\
\hline ITA & & 8.00 & 0.17 & 1.00 & & & 0.02 & 0.47 & -0.84 & -0.86 & 0.34 \\
\hline JPN & & 12.00 & & & 3.80 & 0.12 & 0.21 & 0.37 & -0.44 & -0.20 & 0.47 \\
\hline KOR & 67.37 & 14.55 & & & 6.40 & 0.06 & 0.06 & 0.09 & 0.68 & 0.31 & 0.33 \\
\hline LTU & 85.00 & 8.00 & 0.17 & 0.25 & & 0.06 & 0.03 & 0.19 & & & \\
\hline LUX & & 8.00 & 0.67 & 0.50 & 1.60 & & 0.00 & 0.47 & 1.11 & 1.70 & 0.35 \\
\hline LVA & 92.11 & 8.84 & 0.17 & 0.50 & 0.20 & 0.08 & 0.22 & 0.33 & & & \\
\hline MEX & & & 0.00 & 0.25 & & & 0.11 & 0.46 & 1.21 & -1.90 & -0.27 \\
\hline NLD & 104.11 & 8.00 & & & 34.10 & 0.45 & 0.10 & 0.50 & -1.44 & -0.31 & -2.84 \\
\hline NOR & 85.00 & 10.00 & 0.17 & 0.75 & 4.60 & 0.09 & 0.17 & 0.67 & 0.59 & 0.63 & -2.04 \\
\hline NZL & 85.83 & 8.00 & 0.17 & 0.25 & 5.80 & 0.47 & 0.20 & 0.46 & & & \\
\hline POL & 86.05 & 9.68 & 0.33 & 0.50 & 8.30 & 0.09 & 0.06 & 0.15 & -0.66 & -0.15 & -0.56 \\
\hline PRT & & 8.53 & 0.20 & 0.50 & 2.00 & 0.05 & 0.15 & 0.44 & -0.30 & -0.54 & -0.45 \\
\hline RUS & & & 0.17 & 0.25 & & & & & & & \\
\hline SVK & 78.17 & 8.00 & 0.17 & 0.50 & & & 0.00 & 0.21 & -0.89 & -1.53 & -0.28 \\
\hline SVN & & 8.00 & & & 6.40 & & 0.08 & 0.34 & 0.67 & -1.66 & 0.73 \\
\hline SWE & 85.00 & 8.00 & 0.50 & 0.50 & & 0.45 & 0.06 & 0.24 & 0.68 & 0.40 & 0.52 \\
\hline TUR & 76.04 & & 0.31 & 0.25 & & & 0.07 & 0.36 & & & \\
\hline USA & & 8.00 & 0.17 & 0.25 & 4.30 & 0.10 & 0.40 & 0.58 & 1.20 & -0.89 & -0.31 \\
\hline ZAF & & & & & & & 0.23 & 0.59 & & & \\
\hline
\end{tabular}


Annex E. Housing policies and resilience indicators

\begin{tabular}{|c|c|c|c|c|c|c|}
\hline Business cycles (real GDP) & Duration (boom) & Duration (bust) & Trough-to-peak & Peak-to-trough & Strength of recovery & Time to recovery \\
\hline LTV caps & 1.0 & 1.2 & 1.8 & -1.3 & 2.0 & 0.1 \\
\hline Capital requirements & -0.8 & -0.6 & -0.3 & -1.5 & 1.6 & 0.7 \\
\hline Rent control & 0.9 & -0.4 & 0.1 & 1.0 & -0.1 & 0.7 \\
\hline Tenure security & -1.7 & -0.7 & -2.8 & 1.6 & -0.7 & 0.7 \\
\hline Social rental market & -0.2 & -0.2 & -0.9 & 0.7 & -1.4 & -0.4 \\
\hline Housing allowances & -0.5 & -1.2 & -1.3 & 1.4 & -2.3 & -1.8 \\
\hline Property tax rate (owner) & 1.9 & 0.8 & 0.2 & 0.9 & -0.4 & -0.3 \\
\hline Property tax rate (rental) & -0.1 & -0.8 & -1.7 & 1.9 & -0.2 & -1.9 \\
\hline Urban sprawl restrictiveness & 1.3 & -0.7 & 2.1 & 0.4 & 2.3 & -0.5 \\
\hline Densification restrictiveness & 0.0 & -0.4 & 0.1 & 0.6 & 0.5 & -1.2 \\
\hline Zoning restrictiveness & -1.2 & -0.6 & -1.3 & -0.3 & -1.9 & 0.4 \\
\hline Deviation cycles (output gap) & Duration (boom) & Duration (bust) & Trough-to-peak & Peak-to-trough & Strength of recovery & Time to recovery \\
\hline LTV caps & 1.6 & 1.5 & 0.0 & -1.6 & 1.3 & - \\
\hline Capital requirements & 0.2 & -0.5 & 1.5 & -0.6 & -0.9 & - \\
\hline Rent control & -1.6 & 1.0 & -1.2 & 1.1 & -0.8 & - \\
\hline Tenure security & 0.1 & 1.0 & 0.1 & 0.1 & 0.0 & - \\
\hline Social rental market & 0.3 & 0.7 & -1.0 & 1.3 & -0.8 & - \\
\hline Housing allowances & 1.0 & -1.9 & -1.2 & 2.1 & -1.4 & - \\
\hline Property tax rate (owner) & 0.1 & 0.3 & -2.2 & 1.5 & -1.4 & - \\
\hline Property tax rate (rental) & 1.0 & 1.2 & -0.6 & 1.1 & -0.5 & - \\
\hline Urban sprawl restrictiveness & -0.5 & -0.9 & 0.0 & 0.1 & 1.3 & - \\
\hline Densification restrictiveness & 0.7 & 0.3 & -0.9 & 1.0 & -1.5 & - \\
\hline Zoning restrictiveness & -1.1 & -2.8 & -1.5 & 0.9 & -0.2 & - \\
\hline Housing investment cycles & Duration (boom) & Duration (bust) & Trough-to-peak & Peak-to-trough & Strength of recovery & Time to recovery \\
\hline LTV caps & 1.2 & 0.2 & 0.2 & 0.5 & -1.8 & 1.1 \\
\hline Capital requirements & -1.0 & -1.4 & 1.3 & 0.2 & 0.7 & -1.0 \\
\hline Rent control & 0.3 & -0.2 & 1.3 & -0.7 & 1.7 & 0.5 \\
\hline Tenure security & 0.9 & 1.2 & -0.2 & 1.9 & 0.1 & 0.3 \\
\hline Social rental market & 0.4 & 1.0 & -1.7 & 1.0 & -1.3 & 0.3 \\
\hline Housing allowances & 0.1 & 0.2 & -1.6 & 1.1 & -0.7 & 1.0 \\
\hline Property tax rate (owner) & 0.0 & 0.3 & -2.2 & 1.4 & -2.1 & 0.4 \\
\hline Property tax rate (rental) & -0.1 & -0.2 & -2.2 & 2.7 & -0.9 & -0.9 \\
\hline Urban sprawl restrictiveness & 0.7 & -1.3 & 1.5 & 0.7 & 2.1 & 0.8 \\
\hline Densification restrictiveness & -0.6 & -0.9 & 0.3 & 0.1 & 1.5 & 0.2 \\
\hline Zoning restrictiveness & -1.9 & -0.1 & -0.5 & -0.9 & -1.2 & 1.5 \\
\hline Real house price cycles & Duration (boom) & Duration (bust) & Trough-to-peak & Peak-to-trough & Strength of recovery & Time to recovery \\
\hline LTV caps & 1.2 & -0.1 & 0.8 & -0.2 & 1.5 & -0.8 \\
\hline Capital requirements & -1.2 & -1.1 & -1.2 & 1.2 & -0.4 & -0.2 \\
\hline Rent control & 0.6 & 0.1 & 1.4 & -1.0 & -0.8 & 1.6 \\
\hline Tenure security & 1.1 & 0.3 & 1.8 & -0.5 & -0.9 & 0.9 \\
\hline Social rental market & 1.4 & 0.4 & 1.6 & -0.8 & 0.2 & -0.3 \\
\hline Housing allowances & 1.8 & 1.0 & 1.0 & 0.4 & 0.2 & 1.8 \\
\hline Property tax rate (owner) & 1.3 & -0.4 & 0.2 & 0.0 & -0.7 & 0.1 \\
\hline Property tax rate (rental) & 1.1 & -0.7 & 0.8 & 0.5 & -0.6 & -0.2 \\
\hline Urban sprawl restrictiveness & 0.0 & -1.7 & 0.4 & 0.9 & 2.8 & -1.2 \\
\hline Densification restrictiveness & -0.3 & -2.1 & -0.9 & 2.4 & 1.5 & -0.3 \\
\hline Zoning restrictiveness & 0.3 & 0.9 & 0.1 & -0.5 & -1.0 & 0.3 \\
\hline
\end{tabular}

Note: Cycles are obtained by searching for turning points using the Harding-Pagan (quarterly Bry-Boschan) business cycle dating procedure (Harding and Pagan, 2002[6]). Each of the characteristics of the cycle (column) is regressed one-by-one on the policy variable (row) as observed at the peak. Pooled OLS regressions are used and $\mathrm{t}$-statistics reported. Bold numbers indicate significance at the $10 \%$ level. 


\section{Annex F. Probit estimates}

Table F1. Probit regressions explaining downturn probabilities at a horizon of eight quarters

\begin{tabular}{|c|c|c|c|c|c|c|c|c|}
\hline $\begin{array}{l}\text { Binary dependent variable } 1: \\
1=\text { severe downturn, } 0= \\
\text { otherwise }\end{array}$ & USA & JPN & DEU & GBR & FRA & ITA & CAN & SWE \\
\hline Constant & $-1.48^{* * *}$ & $-7.73^{\star \star *}$ & $-2.81^{\star \star *}$ & $-8.90^{* * *}$ & $-4.03^{\star \star \star}$ & $-7.72^{\star * *}$ & $-6.49^{* * *}$ & $-3.32^{\star * *}$ \\
\hline Yield curve slope ${ }^{3}$ & $-0.75^{\star * *}$ & & & & & & & \\
\hline Unemployment gap ${ }^{4}$ & & & $1.89^{* * *}$ & $1.26^{* *}$ & & & $2.25^{\star \star *}$ & \\
\hline House price-to-rent ratio 5 & $0.24^{* *}$ & $0.28^{* * *}$ & & $0.60^{\star \star *}$ & & & & \\
\hline House price-to-income ratio ${ }^{6}$ & & & & & & $0.06^{* * *}$ & & $0.02^{*}$ \\
\hline Real house prices ${ }^{7}$ & & $1.95^{\star \star *}$ & $0.38^{\star * *}$ & & $0.45^{\star \star *}$ & & $0.57^{\star *}$ & \\
\hline Real share prices ${ }^{8}$ & & & $0.07^{* *}$ & $0.10^{\star \star *}$ & & & $0.09^{\star \star *}$ & \\
\hline Credit-to-GDP ratio ${ }^{9}$ & & & & & $0.64^{* * *}$ & $0.28^{* * *}$ & $0.44^{* * *}$ & $0.18^{* * *}$ \\
\hline OECD credit-to-GDP ratio ${ }^{10}$ & & & & $0.95^{\star *}$ & & $0.31^{* *}$ & & $0.56^{* * *}$ \\
\hline Sample & $\begin{array}{l}\text { 1980Q1- } \\
2018 Q 3\end{array}$ & $\begin{array}{l}\text { 1977Q2- } \\
\text { 2018Q3 }\end{array}$ & $\begin{array}{l}\text { 1975Q2- } \\
\text { 2018Q3 }\end{array}$ & $\begin{array}{l}\text { 1975Q3- } \\
\text { 2018Q3 }\end{array}$ & $\begin{array}{l}\text { 1975Q2- } \\
\text { 2018Q3 }\end{array}$ & $\begin{array}{l}\text { 1976Q2- } \\
\text { 2018Q3 }\end{array}$ & $\begin{array}{l}\text { 1975Q2- } \\
\text { 2018Q3 }\end{array}$ & $\begin{array}{l}\text { 1976Q2- } \\
\text { 2018Q3 }\end{array}$ \\
\hline MCFadden R-Sqd & 0.54 & 0.70 & 0.61 & 0.64 & 0.49 & 0.45 & 0.65 & 0.41 \\
\hline$\%$ of correct predictions ${ }^{2}$ & $92 \%$ & $93 \%$ & $92 \%$ & $90 \%$ & $91 \%$ & $87 \%$ & $90 \%$ & $89 \%$ \\
\hline Downturns & $95 \%$ & $94 \%$ & $96 \%$ & $94 \%$ & $82 \%$ & $96 \%$ & $100 \%$ & $92 \%$ \\
\hline Non-downturns & $91 \%$ & $93 \%$ & $91 \%$ & $90 \%$ & $92 \%$ & $85 \%$ & $89 \%$ & $89 \%$ \\
\hline
\end{tabular}

Notes:

Results from a probit regression at a horizon of 8 quarters. All explanatory variables enter the equations lagged by 8 quarters except house price variables which are lagged an extra quarter and credit variables which are lagged 2 extra quarters (because credit statistics become available two quarters after the other variables).

1) The dependent variable is a binary variable taking the value of 1 in a severe downturn, defined as being during a run of quarters when GDP per capita falls cumulatively by at least $2 \%$ points, and zero otherwise. The definition of downturn periods is different for Japan.

2) Predictions categorised according to a $15 \%$ probability threshold.

3) The slope of the yield curve is measured as the difference between the interest rate on 10-year government bonds and a short-term interest rate, which is usually taken as the rate on a 3-month Treasury Bill.

4) The unemployment gap is the OECD measure of the equilibrium unemployment less the unemployment rate, so that a positive value indicates that the labour market is over-heating.

5) 5-year annual average growth rate.

6) 1-year average (ITA).

7) 3-year annual average growth (DEU, FRA, CAN), 5-year annual average growth (JPN). The specification for Japan uses OECD-wide real house prices. Specifications for Germany and France use euro-area real house prices. The model for Canada uses US real house prices.

8) 3-year annual average growth. The specification for Canada uses OECD-wide real share prices.

9) 3-year annual average change. FRA and ITA specifications use bank credit-to-GDP ratio. SWE specification uses private credit-to-GDP ratio.

10) 3-year annual average change. ITA uses the OECD-wide bank credit-to-GDP ratio.

Statistical significance of coefficients at the $10 \%, 5 \%$ and $1 \%$ levels is denoted with *, ** and ***.

Source: Turner et al. (2018). 
Figure F1. Severe-downturn predictions eight quarters ahead accompanied by confidence bands

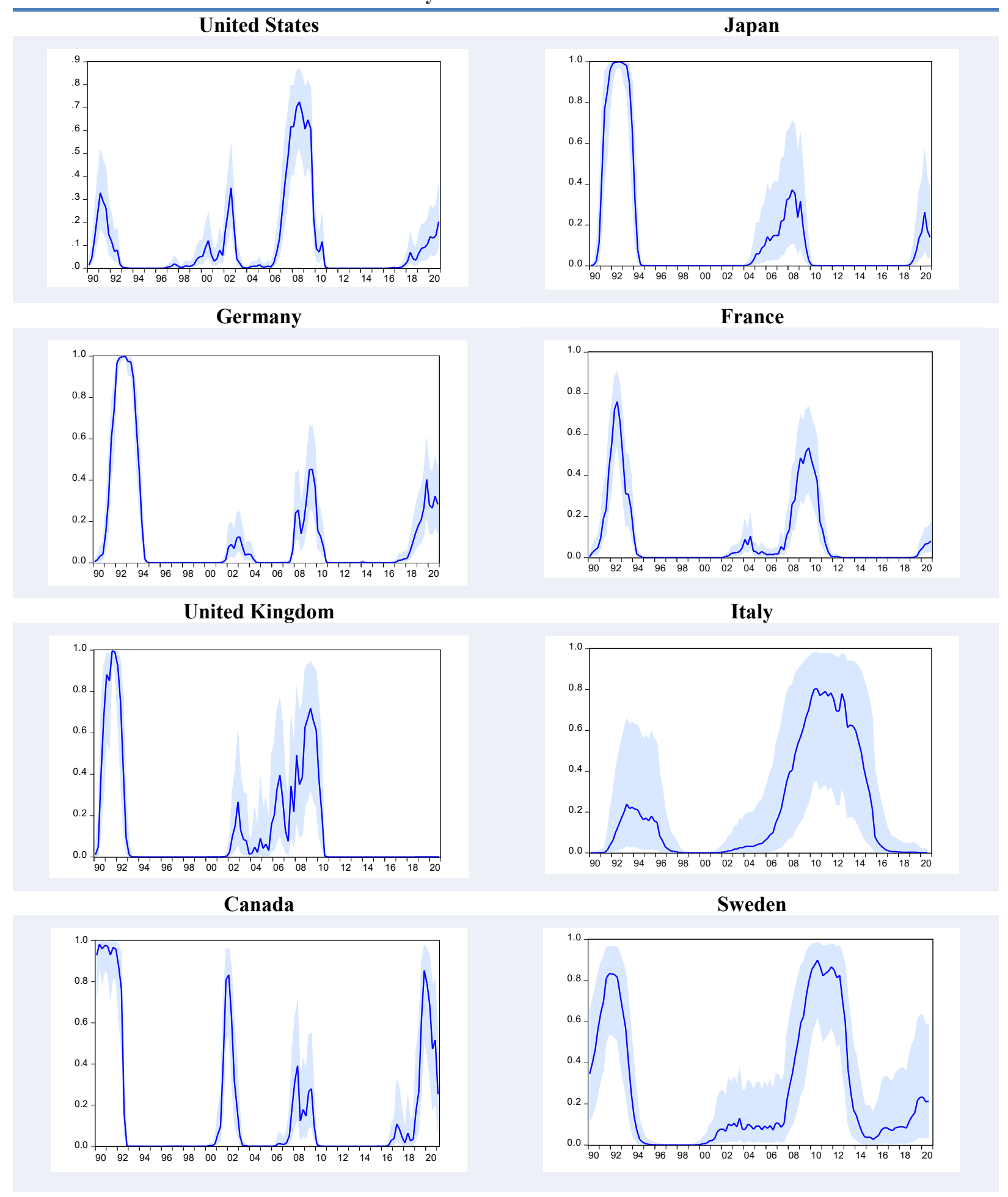

Note: The solid line is the predicted probability of a severe downturn 8 quarters ahead, estimated using probit regressions. The shaded area represents the $95 \%$ confidence intervals around point estimates. The latter have been computed by transforming estimates of the confidence intervals for the linear predictor into probability estimates.

Source: Turner, Chalaux and Morgavi (2018[19]) and authors' calculations. 
Table F2. Decomposition of downturn predictions eight quarters ahead
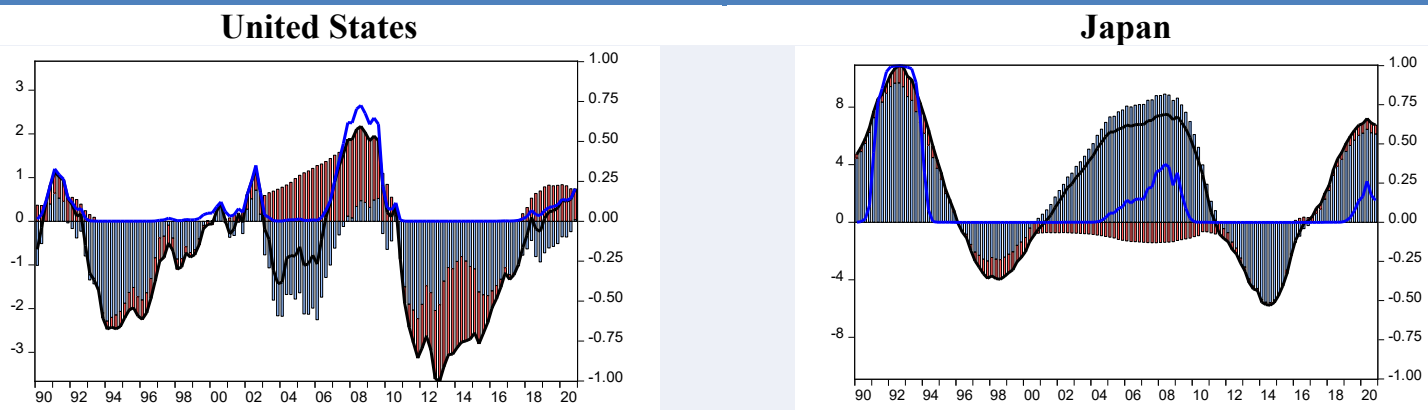

$\square_{\text {Total }}^{\text {Yield curve }} \square_{\text {Probability (right-axis) }}^{\text {House pric-torent ratio }}$

Germany

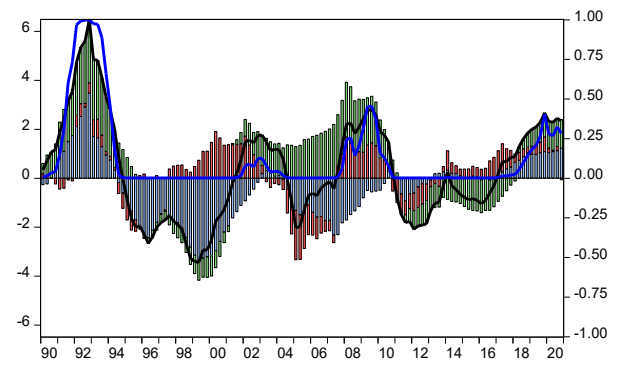

$\square_{\text {Total }}^{\mathrm{OECD} \text { real house prices }} \square_{\text {Probability (right-axis) }}^{\text {House prictont ratio }}$

France
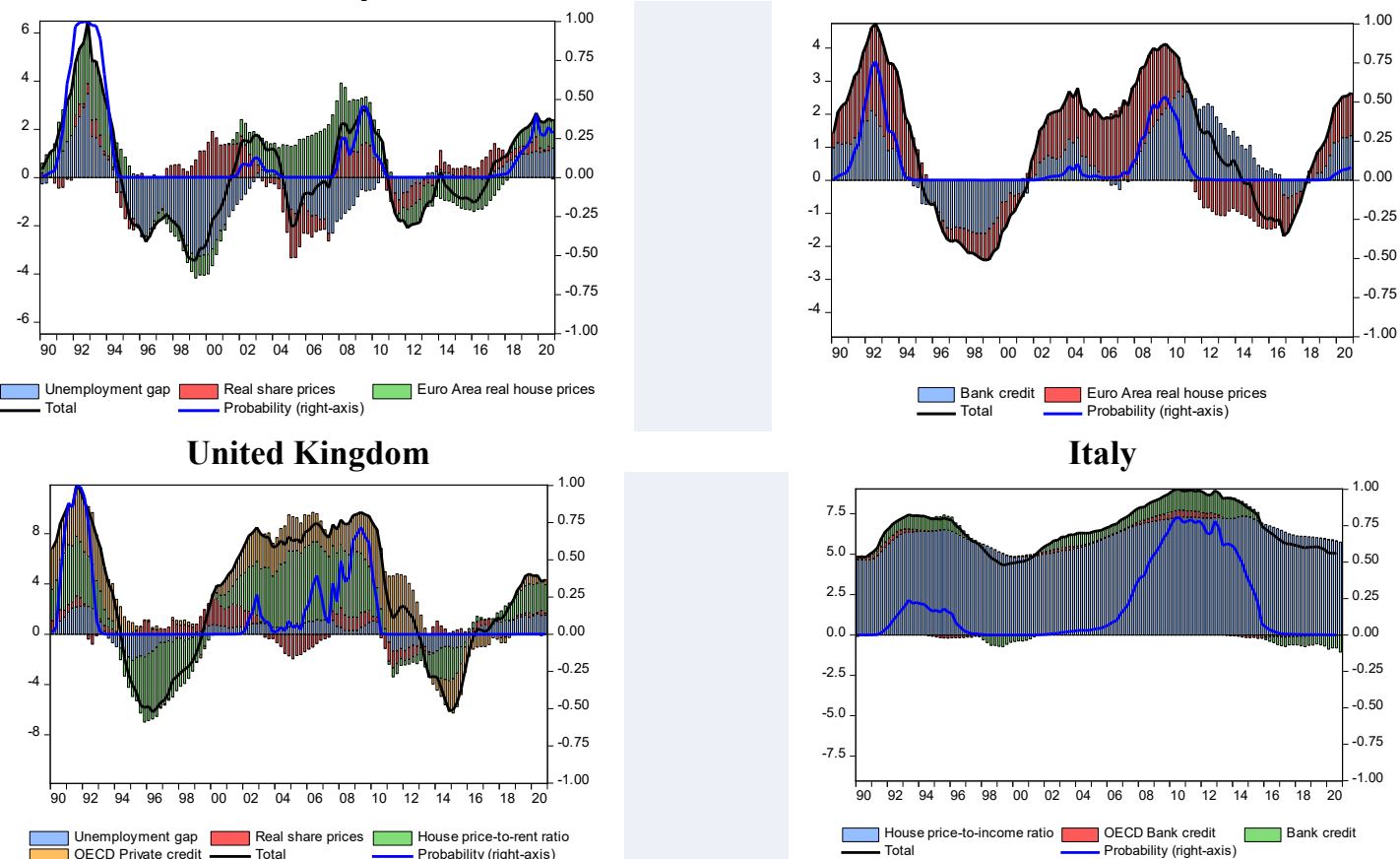

Canada
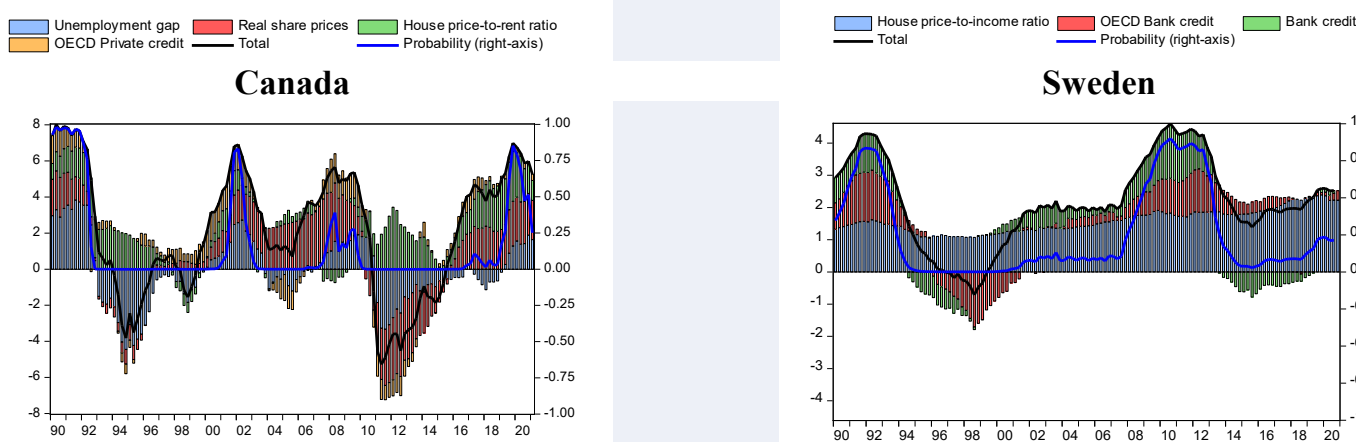

Sweden

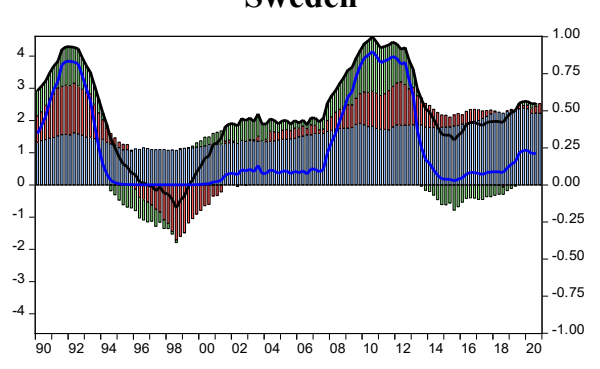

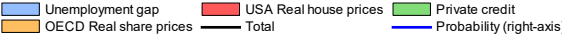

Probability

$\square$ OECD Bank credit

Note: The black 'Total' line is the sum of the contributions of the bars. This variable is a measure of the location of the likelihood on a normal distribution, which is transformed (after inclusion of the constant) into the corresponding probability that a severe downturn occurs, as represented by the blue 'Probability' line, which takes a value between 0 and 1 .

Source: Turner, Chalaux and Morgavi (2018 $[19])$. 